\title{
Theranosties
}

Review

2013; 3(7):448-466. doi: 10.7150/thno.6592

\section{PET Imaging of Inflammation Biomarkers}

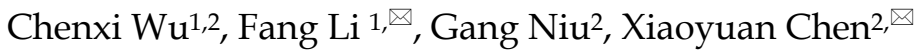

1. Department of Nuclear Medicine, Peking Union Medical College Hospital (PUMCH), Chinese Academy of Medical Sciences \& Peking Union Medical College (CAMS \& PUMC), Beijing, China.

2. Laboratory of Molecular Imaging and Nanomedicine, National Institute of Biomedical Imaging and Bioengineering (NIBIB), National Institutes of Health (NIH), Bethesda, USA.

\footnotetext{
$\bowtie$ Corresponding author: Xiaoyuan Chen (shawn.chen@nih.gov), Fang Li (lifang@pumch.cn).
}

() Ivyspring International Publisher. This is an open-access article distributed under the terms of the Creative Commons License (http://creativecommons.org/ licenses/by-nc-nd/3.0/). Reproduction is permitted for personal, noncommercial use, provided that the article is in whole, unmodified, and properly cited.

Received: 2013.05.0I; Accepted: 2013.05.24; Published: 2013.06.24

\begin{abstract}
Inflammation plays a significant role in many disease processes. Development in molecular imaging in recent years provides new insight into the diagnosis and treatment evaluation of various inflammatory diseases and diseases involving inflammatory process. Positron emission tomography using ${ }^{18}$ F-FDG has been successfully applied in clinical oncology and neurology and in the inflammation realm. In addition to glucose metabolism, a variety of targets for inflammation imaging are being discovered and utilized, some of which are considered superior to FDG for imaging inflammation. This review summarizes the potential inflammation imaging targets and corresponding PET tracers, and the applications of PET in major inflammatory diseases and tumor associated inflammation. Also, the current attempt in differentiating inflammation from tumor using PET is also discussed.
\end{abstract}

Key words: Positron emission tomography, inflammation, molecular imaging, biomarker.

\section{Introduction}

Inflammation acts as the initial host defense against invasive pathogens and other inciting stimulus. It plays an important role in tissue repair and elimination of harmful pathogens. Although the inflammatory response is essential for host defense, it is very much a double-edged sword. Inappropriate inflammatory reaction or delay in the resolution of inflammation will damage adjacent normal cells in the tissue. Microbial infection is most commonly caused by bacteria and viruses, while sterile inflammation is triggered by sterile stimulus involving physical, chemical or metabolic noxiae such as burns, trauma, and dead cells $[1,2]$. Similar to infection, the sterile inflammatory process also includes the recruitment of neutrophils, macrophages, and the production of proinflammatory cytokines and chemokines [3]. Accumulating evidence supports that various human diseases, including stroke, Alzheimer's disease, atherosclerosis, and many autoimmune diseases, are re- lated to sterile inflammation. These diseases happen and evolve, at least in part, due to the improper resolution of inflammatory processes [4].

Molecular imaging can visualize, characterize, and measure the biological processes at the molecular and cellular levels in humans and other organisms [5]. Many imaging techniques are incorporated in the molecular imaging realm, including magnetic resonance imaging (MRI), positron emission tomography (PET), single photon emission computed tomography (SPECT), optical imaging, ultrasound [6], and photoacoustic imaging [7]. Each technique has its own unique applications, advantages, and limitations. Compared with other imaging modalities, PET features high sensitivity and specificity. Therefore, PET has become one of the most frequently used molecular imaging techniques in the clinic. Besides, the hybridization of PET with CT and MR provides additional anatomical details to the lesions, allowing for both 
high sensitivity molecular and anatomical/functional imaging.

${ }^{18} \mathrm{~F}$-FDG (2-deoxy-2-18 F-fluoro-D-glucose) is the most extensively used PET imaging tracer and has been applied successfully in tumor detection, staging, and therapy evaluation, as well as in cardiovascular and neurological diseases [8]. In inflammatory diseases, ${ }^{18}$ F-FDG PET also has its value, particularly in atherosclerosis and some arthritis diseases $[9,10]$ (Table 1). However, ${ }^{18}$ F-FDG PET imaging of inflammation tends to give false-positive results, especially in patients with cancer. Moreover, the high tracer accumulation in the heart and brain makes it difficult to detect inflammatory foci near those organs or tissues. Consequently, new imaging tracers and targets for more specific inflammation detection and therapy evaluation are under intensive investigation. PET imaging with these new tracers greatly improved our understanding of the mechanism of inflammation and increased the diagnostic specificity and accuracy of inflammatory foci. As summarized in Figure 1, various radiopharmaceuticals have been developed for PET imaging of inflammation, targeting different biomarkers from macrophages to angiogenesis. In this review, we will summarize these potential imaging targets and tracers for inflammation PET imaging, the applications of PET in major inflammatory diseases, and tumor associated inflammation imaging. The current attempt to differentiate inflammation from tumor using PET is also elaborated. A discussion of pathogen targeted PET imaging is beyond the scope of this review.

\section{Inflammatory foci}

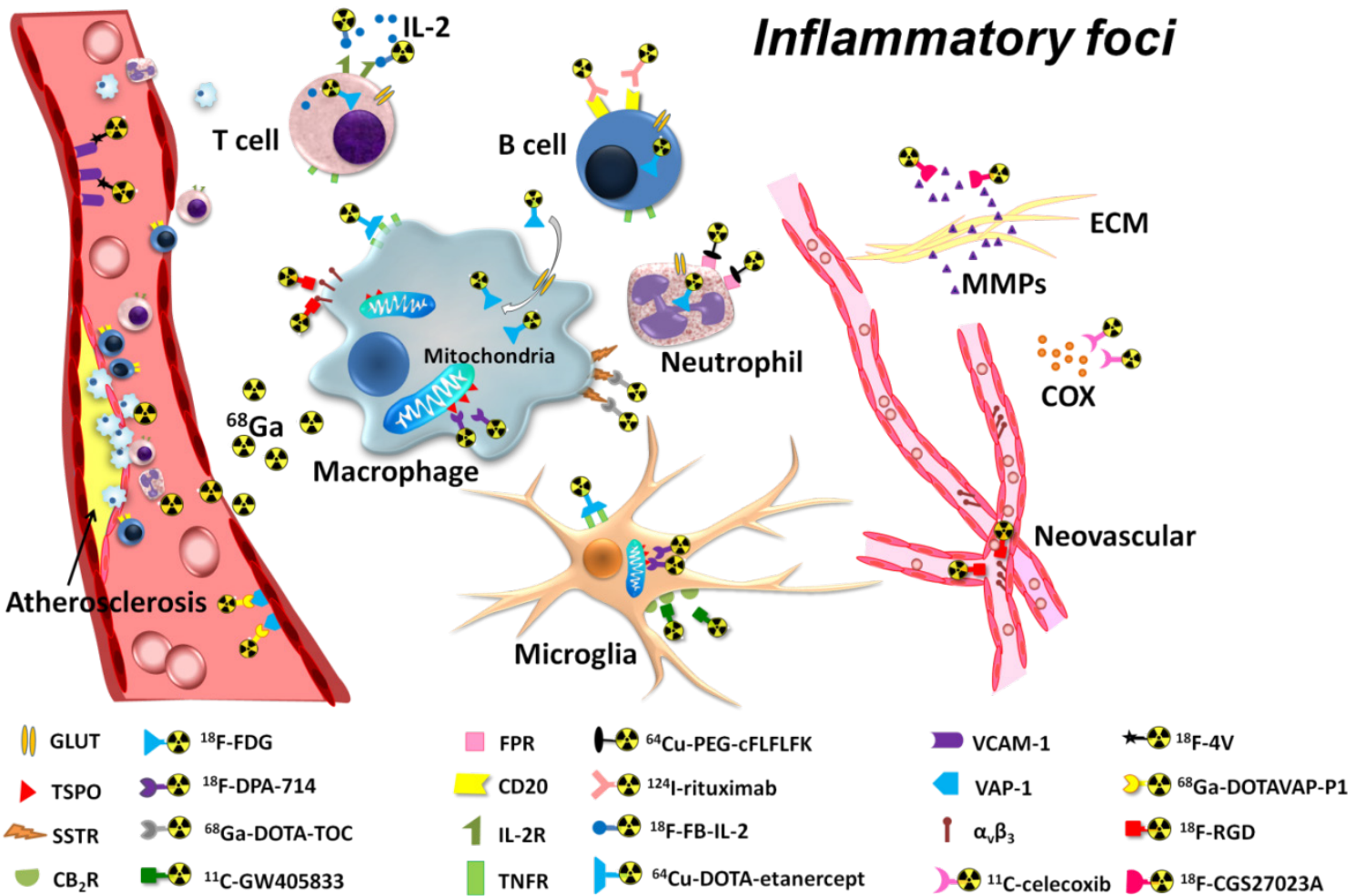

Figure I. PET inflammation imaging biomarkers within the inflammatory foci.

Table I. ${ }^{18} \mathrm{~F}$-FDG imaging of sterile inflammatory diseases.

\begin{tabular}{|c|c|c|c|c|}
\hline Diseases & Study type & References & Tracers & Remarks \\
\hline \multirow[t]{3}{*}{$\begin{array}{l}\text { Atherosclerotic } \\
\text { inflammation }\end{array}$} & Clinical & $\mathrm{Li}, 2012[11]$ & ${ }^{18} \mathrm{~F}-\mathrm{FDG},{ }^{68} \mathrm{Ga}-\mathrm{DOTATATE}$ ( PET/CT) & $\begin{array}{l}\text { In patients with neuroendocrine } \\
\text { tumors or thyroid cancer }\end{array}$ \\
\hline & Preclinical & Silvola, 2011 [12] & ${ }^{18} \mathrm{~F}-\mathrm{FDG},{ }^{68} \mathrm{Ga}($ microPET/CT) & In LDLR $/-$ ApoB100/100 mice \\
\hline & Clinical & Yarasheski, 2012 [13] & ${ }^{18} \mathrm{~F}-\mathrm{FDG}(\mathrm{PET} / \mathrm{CT})$ & In HIV-infected patients \\
\hline \multirow[t]{3}{*}{ Vasculitis } & Clinical & Bissonnette, 2012 [14] & ${ }^{18} \mathrm{~F}-\mathrm{FDG}(\mathrm{PET} / \mathrm{CT})$ & In psoriasis patients \\
\hline & Clinical & Maki-Petaja, 2012 [15] & ${ }^{18} \mathrm{~F}-\mathrm{FDG}(\mathrm{PET} / \mathrm{CT})$ & $\begin{array}{l}\text { Anti-TNF therapy, in rheumatoid } \\
\text { arthritis patients }\end{array}$ \\
\hline & Clinical & Tegler, 2012 [16] & ${ }^{18} \mathrm{~F}-\mathrm{FDG}(\mathrm{PET} / \mathrm{CT})$ & Aortic aneurysms \\
\hline
\end{tabular}




\begin{tabular}{|c|c|c|c|c|}
\hline & Clinical & Tezuka, 2012 [17] & ${ }^{18} \mathrm{~F}-\mathrm{FDG}(\mathrm{PET} / \mathrm{CT})$ & Takayasu arteritis \\
\hline & Clinical & Sarda-Mantel, 2012 [18] & ${ }^{18} \mathrm{~F}-\mathrm{FDG},{ }^{18} \mathrm{~F}-\mathrm{DPA} 714,{ }^{18} \mathrm{~F}-\mathrm{FCH}$ (PET) & Abdominal aneurysms \\
\hline & Clinical & Kim, 2010 [19] & ${ }^{18} \mathrm{~F}-\mathrm{FDG}(\mathrm{PET} / \mathrm{CT})$ & In T2DM patients \\
\hline Valvular inflammation & Clinical & Dweck, 2012 [20] & ${ }^{18} \mathrm{~F}-\mathrm{FDG},{ }^{18} \mathrm{~F}-\mathrm{NaF}$ (PET/CT) & \\
\hline \multirow[t]{2}{*}{ Arthritis } & Preclinical & Irmler, 2010 [21] & ${ }^{18} \mathrm{~F}-\mathrm{FDG}(\mathrm{PET} / \mathrm{CT})$ & With etanercept therapy \\
\hline & Clinical & Yamashita, 2012 [22] & ${ }^{18} \mathrm{~F}-\mathrm{FDG}(\mathrm{PET} / \mathrm{CT})$ & $\begin{array}{l}\text { Differentiation among PMR, SpA } \\
\text { and RA }\end{array}$ \\
\hline \multirow[t]{2}{*}{ Skin inflammation } & Preclinical & McLarty, 2011 [23] & ${ }^{18} \mathrm{~F}-\mathrm{FDG},{ }^{18} \mathrm{~F}-$ scyllo-inositol (microPET) & \\
\hline & Preclinical & Autio, 2010 [24] & $\begin{array}{l}{ }^{18} \mathrm{~F}-\mathrm{FDG},{ }^{68} \mathrm{Ga}-\mathrm{DOT} A V A P-P 1 \\
\text { mal/brain PET) }\end{array}$ & \\
\hline Bone inflammation & Preclinical & Brown, 2012 [25] & ${ }^{18} \mathrm{~F}-\mathrm{FDG}$ (microPET) & Differentiation with osteomyelitis \\
\hline $\begin{array}{l}\text { Myocardial } \\
\text { inflammation }\end{array}$ & Clinical & Lee, 2012 [26] & ${ }^{18} \mathrm{~F}-\mathrm{FDG}(\mathrm{PET} / \mathrm{MR})$ & Post-myocardial infarction \\
\hline
\end{tabular}

TNF: tumor necrosis factor T2DM: Type 2 Diabetes Mellitus RA: rheumatoid arthritis PMR: polymyalgia rheumatic SpA: seronegative spondyloarthritis.

\section{Biomarkers for inflammation imaging}

After being triggered by various stimuli, the inflammation cascade begins with the release of various pro-inflammatory mediators including cytokines, chemokines, and leukotrienes by resident inflammatory and endothelial cells. Next, vascular permeability is increased with the infiltration of neutrophils and macrophages. In the late phase, the release of pro-resolving mediators causes apoptosis of inflammatory cells and leads to the termination of inflammation. All these key inflammatory mediators and specific features of dominant inflammatory cells are potential targets for either visualization or treatment of inflammatory disorders. In this section, we will cover the major biomarkers of inflammation and the corresponding probes for PET imaging, including the metabolic rate and membrane markers of inflammatory cells, cytokines, and vessels within inflamed foci, as well as some newly identified inflammation related targets.

\section{I Metabolic activity of inflammatory cells}

\section{I.I Glucose metabolism}

High glucose metabolism and consequent high FDG accumulation are not unique phenomena for malignant cells. Benign processes including inflammatory disorders also show increased FDG uptake, which bring about false positiveness in tumor detection [27]. As the key indicators and core participants in inflammatory foci, infiltrating inflammatory cells utilize glucose at a much higher level than peripheral non-inflammatory cells. Therefore, the increased glucose metabolism of inflamed foci due to oxidative burst in the inflammatory cells become an important and most frequently used target in PET imaging of inflammation. CT or MRI is often combined with ${ }^{18}$ F-FDG PET to increase the diagnostic accuracy. Indeed, ${ }^{18}$ F-FDG has been used intensively in a great number of inflammatory diseases and therapy evaluations, part of which are summarized in Table 1. For details of the applications of ${ }^{18} \mathrm{~F}-\mathrm{FDG}$ in inflammation imaging, please refer to previously published review articles [28, 29].

\subsubsection{Choline metabolism}

Choline is an important precursor of phosphatidylcholine and sphingomyelin, two classes of phospholipids that are abundant in cell membranes. The phosphatidylcholine catabolism by many nucleated cells, mostly proliferative cells, serves as an imaging target both in cancers and in some inflammatory diseases. PET using radiolabeled choline has been used to image prostate cancer [30-33]. By targeting the macrophages and monocytes in inflammatory diseases, choline is also used to image atherosclerosis [34-36] and to evaluate necrosis after brain tumor radiation therapy [37]. Matter et al. found via ex vivo micro-autoradiography that ${ }^{18 \mathrm{~F}-c h o l i n e}$ had greater sensitivity in detecting atherosclerotic plaques than FDG (84\% versus 64\%) [34]. In a clinical setting with five patients, Bucerius et al. [36] demonstrated the feasibility of ${ }^{18} \mathrm{~F}$-choline to image structural wall alteration in humans. A major advantage offered by ${ }^{18} \mathrm{~F}$-choline imaging over ${ }^{18} \mathrm{~F}-\mathrm{FDG}$ is the lack of ${ }^{18} \mathrm{~F}$-choline uptake in the myocardium [38]. Thus choline may be superior to FDG in detecting coronary plaques. 
Table 2. PET imaging targets for inflammation and corresponding PET probes.

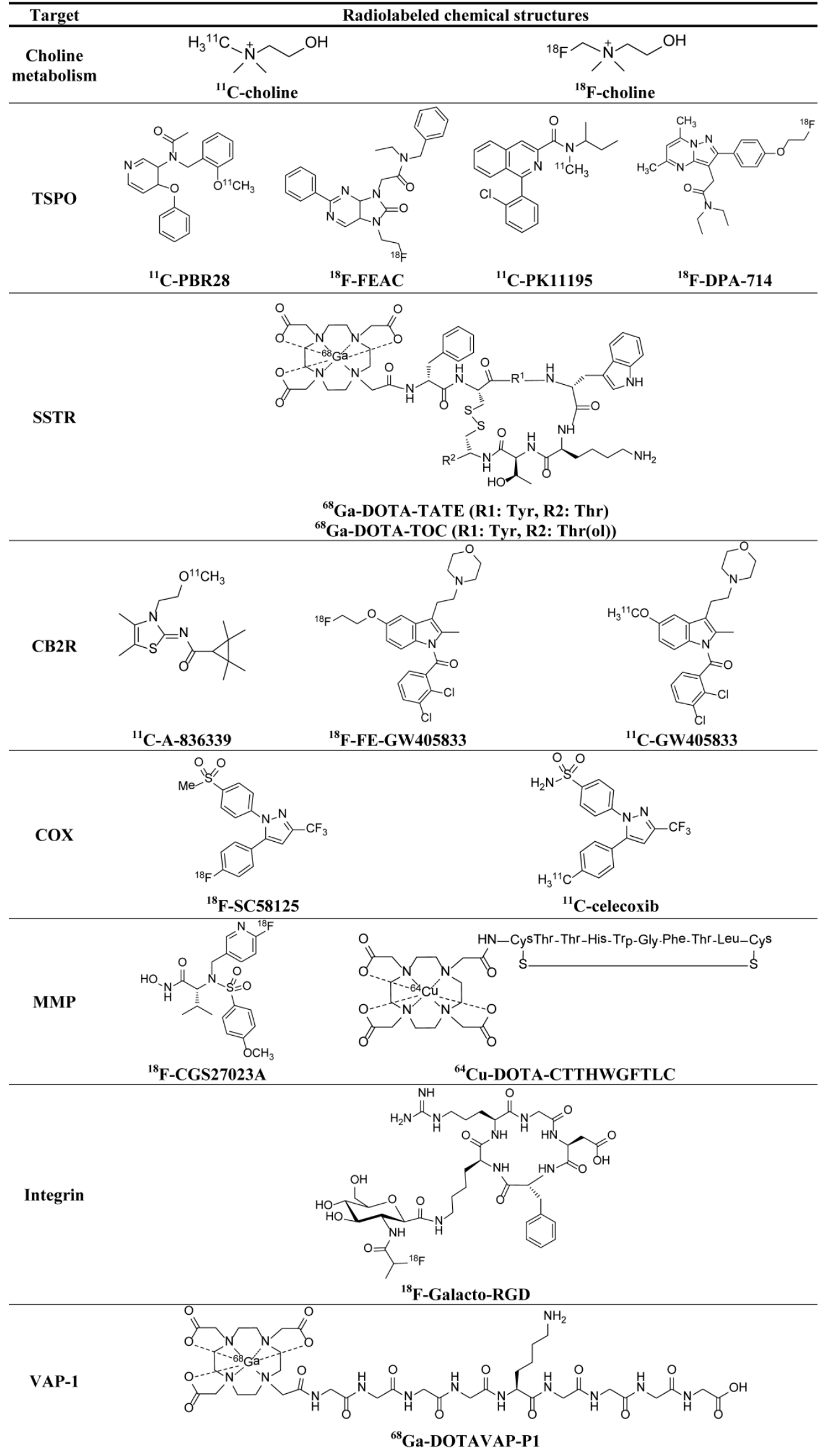




\subsection{Membrane markers of inflammatory cells}

\subsection{Translocator protein (TSPO)}

Formerly known as peripheral benzodiazepine receptor (PBR), the $18 \mathrm{kDa}$ translocator protein is located on the outer mitochondrial membrane and can bind with cholesterol and various classes of drug ligands. TSPO is ubiquitously expressed in peripheral tissues but is only minimally expressed in the healthy human brain. Previous studies found high TSPO expression in macrophages, neutrophils, lymphocytes [39-41], activated microglia, and astrocytes [42-46]. Microglia have been found to contribute to neuroinflammation in many types of central nervous system (CNS) disorders, such as stroke, multiple sclerosis (MS) [45], Alzheimer's disease (AD) [47], Parkinson's disease (PD) [48], amyotrophic lateral sclerosis (ALS) [49], and epilepsy [50]. Therefore, TPSO expressed on microglial cells in CNS emerges as a promising target for PET imaging of neuroinflammation. The most studied PET tracers binding to TPSO are ${ }^{11} \mathrm{C}$ or ${ }^{18} \mathrm{~F}-$ labeled isoquinoline carboxamide PK11195 (1-(2-chlorophenyl)-N-methyl-N-(1-methylpropyl)-3-i soquinoline carboxamide) [40,43] and more recently ${ }^{11} \mathrm{C}-\mathrm{PBR} 28$ ( $\mathrm{N}-\left(2-\left[{ }^{11} \mathrm{C}\right] \mathrm{methoxybenzyl}\right)-\mathrm{N}-(4$-phenoxy- pyridin-3-yl)acetamide) [42, 51]. Syntheses of these tracers are now mostly automated and are efficient, which guarantees the future application in the clinic. In preclinical studies, for example, Yui et al. [52] used TSPO radioligands ${ }^{18} \mathrm{~F}-\mathrm{FEAC}$ ( $N$-benzyl- $N$-ethyl-2[7,8-dihydro-7-(2-18F-fluoroethyl)-8-oxo-2-phenyl-9Hpurin-9-yl]acetamide) and 18F-FEDAC ( $N$-benzyl$N$-methyl-2-[7,8-dihydro-7-(2-18F-fluoroethyl)-8-oxo-2 -phenyl-9H-purin-9-yl]acetamide) in a rat brain ischemia model and found both tracers could accumulate in the infarct areas, and the uptake could be inhibited by pretreatment with TSPO ligands PK11195 or AC-5216 (N-benzyl-N-ethyl-2-(7-methyl-8-oxo-2phenyl-7,8-dihydro-9H-purin-9-yl)acetamide) (Figure 2). In an AD model, Maeda et al. [53] found elevated TSPO levels in tau-rich hippocampus and entorhinal cortex region of the brain by ${ }^{11} \mathrm{C}-\mathrm{AC}-5216$ microPET, and there was a constant increase of tracer uptake in the brain region with the progression of $\mathrm{AD}$. In a clinical study, Gulyás et al. used ${ }^{11} \mathrm{C}$-vinpocetine (ethyl apovincaminate) to evaluate the TSPO levels in the brains of stroke patients and found different uptake patterns in ischemic cores and peri-infarct zone over time [54].
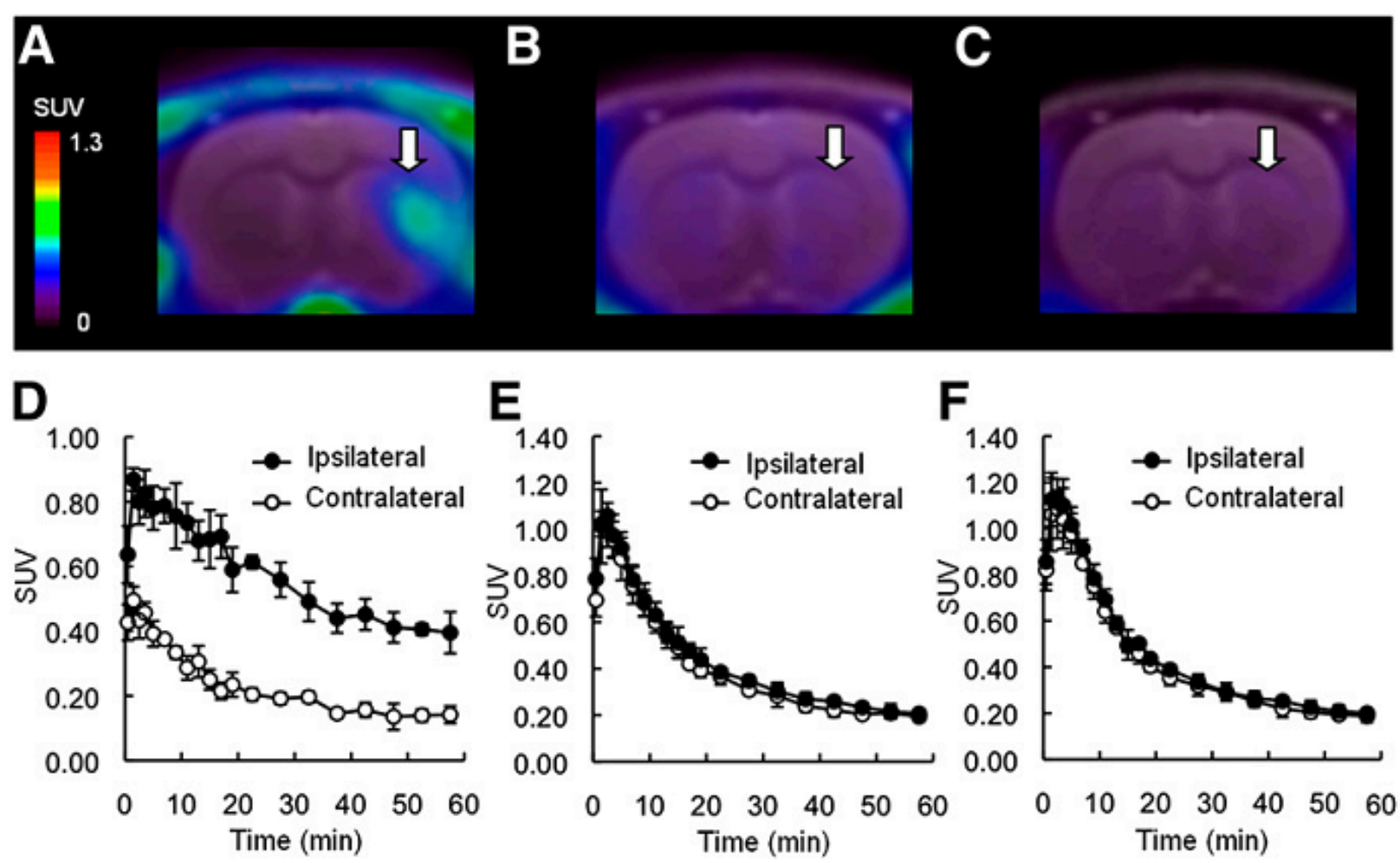

Figure 2. Representative PET images and time activity curves of ${ }^{18} \mathrm{~F}-\mathrm{FEAC}$ in infarcted rat brains 7 days after surgery. PET images were generated by averaging the whole 60-min scans and were overlaid on MR images. Arrows indicate infarcted areas. Shown are control rats (A and D), rats pretreated with $A C-5216$ (B and $E)$, and rats pretreated with PKIII95 (C and F) (Yui, 2010 [52]). 

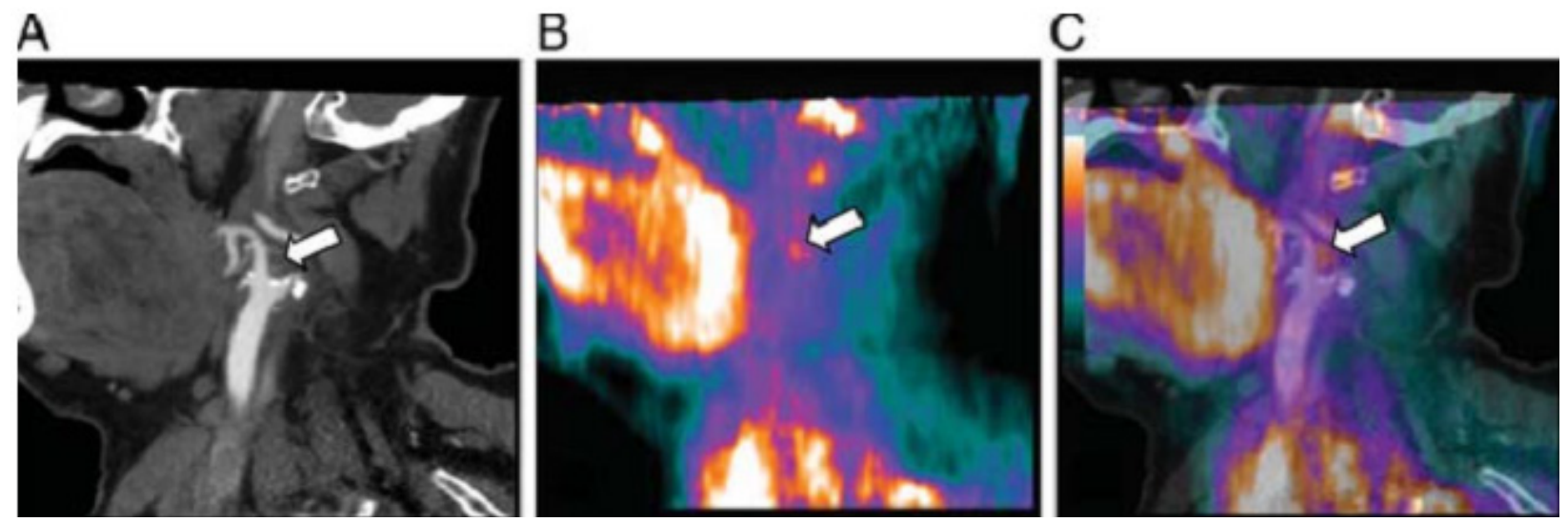

Figure 3. Computed tomography angiography (A), "C-PKIII 95 PET (B), and PET/CT fusion (C) in a 52-year-old patient with right amaurosis fugax 2 weeks prior to the scans. The white arrows denote a focal area of "C-PKIII 95 uptake in the carotid bifurcation (Gaemperl, 20II [40]).

PET imaging using TSPO as an inflammation biomarker has also been reported for atherosclerosis detection with promising results $[39,40,55,56]$. Using autoradiography, Bird and colleagues [39] found both ${ }^{3} \mathrm{H}-\mathrm{DAA} 1106$ ((N-5-fluoro-2-phenoxyphenyl)-N-(2,5dimethoxybenzyl)acetamide) and ${ }^{3} \mathrm{H}-(\mathrm{R})-\mathrm{PK} 11195$ have the potential to quantify the macrophage content in human atherosclerotic plaques obtained from six patients. More recently, Gaemperl et al. [40] successfully applied ${ }^{11}$ C-PK11195 to image intraplaque inflammation in carotid atherosclerosis in 36 patients with carotid stenosis and found a significant correlation between ${ }^{11}$ C-PK11195 uptake ratio and autoradiographic measurement of TSPO binding sites (Figure 3).

TSPO PET has also been used to image inflamed lung and liver diseases. In normal lungs, TPSO is expressed in bronchial, bronchiole epithelium, and submucosal glands in intrapulmonary bronchi. In a lipopolysaccharide induced infectious lung inflammation model, PET imaging using TSPO radio-ligands ${ }^{18}$ F-FEDAC, ${ }^{11} \mathrm{C}-(\mathrm{R})-\mathrm{PK} 11195$ [41], and ${ }^{123}$ I-(R)-PK11195 [57] all showed significant lung lesion uptake, mainly from activated neutrophils and macrophages. Due to its higher lesion accumulation, ${ }^{18}$ F-FEDAC was claimed to be superior to ${ }^{11} \mathrm{C}-(\mathrm{R})-\mathrm{PK} 11195$. In a mouse model of non-alcoholic fatty liver disease (NAFLD), Xie et al. confirmed from autoradiography and histopathology that ${ }^{18} \mathrm{~F}-\mathrm{FEDAC}$ uptake in NAFLD was mainly from injured hepatocytes and $\mathrm{CD}_{11} \mathrm{~b}^{+}$macrophages/activated lymphocytes located in the necroinflammatory loci [58], suggesting that inflammation may also contribute to NAFLD process, and ${ }^{18} \mathrm{~F}-\mathrm{FEDAC}$ may be a potential tracer for NAFLD imaging.

\subsubsection{Somatostatin Receptor}

Somatostatin receptor (SSTR) has been investi- gated as a target for neuroendocrine tumor imaging. SPECT imaging of SSTR expression in neuroendocrine tumors has been well-established for lesion detection and therapeutic monitoring [59-62]. Since a high level of SSTR expression was found on activated lymphocytes and macrophages [63], this receptor has the potential to be used as a new target for inflammation imaging. Compared with tumor imaging, only limited studies have reported using PET tracers to target SSTR in inflammatory disorders or diseases with mild/intense inflammatory infiltration, including atherosclerotic inflammation [11, 64], inflamed pulmonary fibrosis [65], carcinoids, and inflammatory myofibroblastic tumors [66].

TATE (Tyr ${ }^{3}$-octreotate) and TOC (Tyr ${ }^{3}$-octreotide) are analogues of octreotide that bind to the somatostatin type 2 receptor (SSTR-2). 1,4,7,10-Tetraazacyclododecane-N,N',N",N"'-tetraacet ic acid (DOTA) conjugation of these peptides allows for stable chelation to a variety of radiometals such as ${ }^{111} \mathrm{In},{ }^{177} \mathrm{Lu},{ }^{90} \mathrm{Y},{ }^{68} \mathrm{Ga}$ and ${ }^{64} \mathrm{Cu}[67-69]$. In atherosclerosis imaging, clear plaque uptake of ${ }^{8} \mathrm{Ga}$-DOTA-TATE or ${ }^{68} \mathrm{Ga}$-DOTA-TOC in carotid arteries was found, and the uptake has strong association with known risk factors of cardiovascular disease. Due to the much lower uptakes in myocardium, these tracers provided clearer and more consistent detection of macrophage accumulation than FDG in coronary arteries plaques $[70,71]$.

\subsubsection{Type 2 Cannabinoid Receptor $\left(\mathrm{CB}_{2} \mathrm{R}\right)$}

There are at least two subtypes of CBRs in the endocannabinoid system. $\mathrm{CB}_{1} \mathrm{R}$ is involved in the immune system and mainly expressed in the CNS. $\mathrm{CB}_{2} \mathrm{R}$ is expressed at a much lower level in the normal brain tissue compared to $\mathrm{CB}_{1} \mathrm{R}$. Under pathological conditions, especially immune-mediated pathologies, up-regulation of $\mathrm{CB}_{2} \mathrm{R}$ is found on activated microglia, 
the resident immune cells in the CNS [72]. Three major groups of $\mathrm{CB}_{2} \mathrm{R}$ ligands can be labeled with radioisotopes for PET, including pyrazole derivatives, indole derivatives, and quinoline derivatives [73]. For ${ }^{11} \mathrm{C}$-labeling of pyrazole derivatives, a boron precursor was first synthesized and later reacted with ${ }^{11} \mathrm{C}$-methyl iodide via a Suzuki coupling [74]. Indole derivatives such as GW405833 (1-(2,3-dichlorobenzoyl)-5-methoxy-2-methyl-3-[2-(4morpholinyl)ethyl]-1H-indole) are usually labeled with ${ }^{18} \mathrm{~F}$ by alkylation of the phenol precursor with 1-bromo-2-18F-fluoroethane [75]. Labeling the quinoline derivatives was readily achieved by methylating the precursor 7-methoxy-2-oxo-6-pentyloxy-1,2dihydroquinoline-3-carboxylic acid with methyl triflate [73]. The first in vivo PET of brain $\mathrm{CB}_{2} \mathrm{R}$ was performed in 2010 by Horti and his group [76]. Mice with lipopolysaccharide induced neuroinflammation showed a significant increase in ${ }^{11} \mathrm{C}-\mathrm{A}-836339$ uptake in all brain regions. The uptake could be blocked by a $\mathrm{CB}_{2} \mathrm{R}$ selective ligand, indicating the specificity of the tracer accumulation. In the same study, brain uptake of ${ }^{11} \mathrm{C}-\mathrm{A}-836339$ (2,2,3,3-tetramethylcyclopropanecarboxylic acid (3-(2-methoxy-ethyl)-4,5-dimethyl-3Hthiazol-(2Z)-ylidene)amide) uptake in $\mathrm{AD}$ mice was blocked only in regions with high $\mathrm{A} \beta$ amyloid deposition. In another imaging study, Even et al. used two tracers, ${ }^{11} \mathrm{C}-\mathrm{Sch} 225336$ (N-[(1s)-1-[4-[[4-methoxy-2[(4-[11C]methoxyphenyl)sulfonyl)-phenyl]sulfonyl] phenyl]ethyl]methanesulfonamide] and ${ }^{18} \mathrm{~F}-\mathrm{FE}-$ GW405833, and found intense tracer accumulation in the brain of a rat model with $\mathrm{hCB}_{2} \mathrm{R}$ overexpression in the right striatum [75, 77]. Vandeputte et al. [78] imaged brain $\mathrm{CB}_{2} \mathrm{R}$ based on a reporter gene system, in which ${ }^{11} \mathrm{C}-\mathrm{GW} 405833$ clearly accumulated in the brain region with pre-injection of adeno-associated virus $(A A V)$ vectors encoding $h \mathrm{hCB}_{2} \mathrm{R}$. These promising results on $\mathrm{CB}_{2} \mathrm{R}$ targeted PET imaging warrant further applications in a wide range of neuroinflammatory diseases and evaluation of the therapeutic value of novel $\mathrm{CB}_{2} \mathrm{R}$-related drugs. However, the exact role of $\mathrm{CB}_{2} \mathrm{R}$ in $\mathrm{CNS}$ still remains to be fully elucidated, and more in vivo studies using relevant disease models should be conducted to get a better understanding.

\subsubsection{Other membrane markers on inflammatory cells}

Formyl peptide receptor (FPR) is a type of G-protein coupled receptor expressed on neutrophils, responsible for the leukocyte migration cascade in the inflammation process. Using FPR-specific ligand cFLFLFK, neutrophil infiltration in the inflammatory foci could be visualized with various imaging modalities, including MRI [79], optical imaging [80], SPECT [81] and PET $[82,83]$. PET, using cFLFLFK-PEG- ${ }^{64} \mathrm{Cu}$, could visualize inflammatory foci within the lung in an animal model of lung inflammation induced by Klebsiella pneumonia [82]. Moreover, B lymphocyte CD20 antigen imaging has been utilized to visualize synovial membrane in patients with rheumatoid arthritis [84]. Rituximab, an anti-CD20 monoclonal antibody, was radiolabeled with ${ }^{124}$ I for PET/CT imaging in six patients with rheumatoid arthritis. ${ }^{124}$ I-rituximab showed increased uptake in most clinically symptomatic joints, indicating the infiltration of B lymphocytes.

\subsection{Inflammatory cytokines}

\subsubsection{COX}

Cyclooxygenase (COX), also known as prostaglandin $\mathrm{H}$, is an enzyme responsible for the conversion of arachidonic acid into prostaglandins. COX is the target of non-steroidal anti-inflammatory drugs (NSAIDs) [85] . In addition, COX is an integral membrane glycoprotein which can be induced by acute and chronic inflammatory stimulations. Thus far, three COX subtypes (COX-1, 2, and 3) have been identified. Among them, the inducible isoform COX-2 plays a pivotal role in cancer, cardiac/cerebral ischemia, Alzheimer's/Parkinson's disease, and response to inflammatory stimuli, especially neuroinflammation $[86,87]$. Celecoxib (4-(5-p-tolyl-3-trifluoromethylpyrazol-1-yl)benzenesulfonamide) is broadly used as a selective COX-2 inhibitor to treat inflammatory diseases. Imaging tracers have also been developed using celecoxib and some other COX inhibitors by radiolabeling them with either ${ }^{18} \mathrm{~F}$ or ${ }^{11} \mathrm{C}$. Reported PET tracers include ${ }^{18 \mathrm{~F}-d e s b r o m o-D u p-697}$ (2-(4-18F-fluorophenyl)-3-[4-(methylsul-fonyl)phenyl]t hiophene) [88], ${ }^{18} \mathrm{~F}-S C 58125$ (1-[4-(methylsulfonyl) phenyl]-5-(4-18F-fluorophenyl)-3-(trifluoromethyl)-

1H-pyrazole) [89], ${ }^{11}$ C-celecoxib [90], and ${ }^{11} \mathrm{C}$-rofecoxib (4-(4-11C-methylsulfonylphenyl)-3phenyl-5H-furan-2-one) [91]. They have been used to image neuroinflammations [91-93], tumors [94-96], or experimental skin inflammation [96]. However, most of the tracers showed unsatisfactory ex vivo or in vivo properties due to either non-specific bindings or low sensitivity in inflammatory foci, or both. Recently, Uddin et al. [96] reported an ${ }^{18} \mathrm{~F}-$-labeled celecoxib derivative in a rat skin model of inflammation. This derivative featured higher COX-2 inhibitory activity than celecoxib but much less defluorination rate than other ${ }^{18} \mathrm{~F}$-based agents. From microPET/CT imaging, they found significant tracer uptake in the inflamed paw induced by carrageenan, which could be inhibited by celecoxib pretreatment, indicating the specificity of the tracer (Figure 4). 


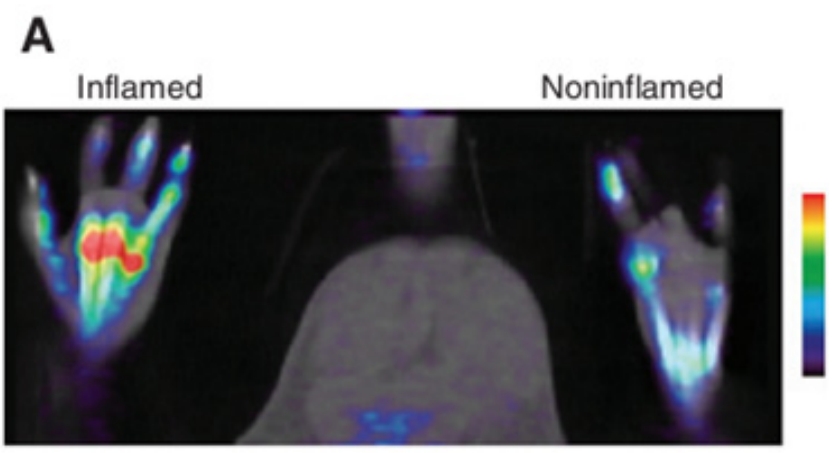

B

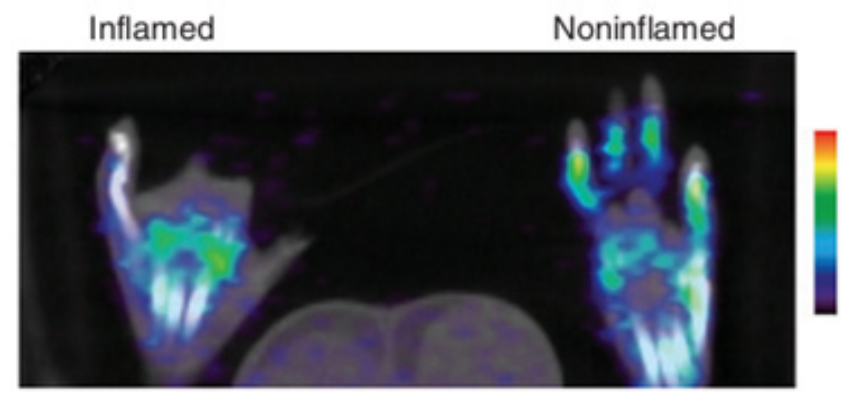

Figure 4. (A) COX-2 targeted microPET/CT imaging of mouse paw inflammation induced by carrageenan. The PET image shows that the radiotracer targeted the swollen footpad (inflamed) selectively over the contralateral footpad (control). (B) PET image of rats with paw inflammation predosed with celecoxib (Uddin, 20II [96]).

\subsubsection{MMP}

Matrix metalloproteinases (MMPs) are zinc- and calcium-dependent metalloproteases, which can degrade protein components of the extracellular matrix (ECM) [97-100]. MMPs and its inhibitors, MMPIs, control the balance of extracellular proteolysis, while increased MMPs activity is considered critical in many pathological processes including cancer, atherosclerosis, and some other inflammatory conditions. Therefore, in vivo imaging of MMP activity would be useful to detect MMPs in these disorders. The activity of MMPs has been visualized by various probes using optical imaging, which has been summarized in several previously published review articles [101, 102]. Quite a few MMPIs have been successfully radiolabeled as imaging tracers, mainly for breast cancer detection [103]. ${ }^{99 \mathrm{mTC}}$ and ${ }^{123}$ I coupled SPECT tracers targeting MMP have been broadly applied in vascular inflammation [104, 105] as well as tumor imaging. Several PET tracers have been reported, such as ${ }^{64} \mathrm{Cu}$-DOTA-CTTHWGFTLC [106], ${ }^{18} \mathrm{~F}-\mathrm{CGS} 27023 \mathrm{~A}$ ((R)-2-(N-((6-18 F-fluoropyridin-3-yl)methyl)-4-methox yphenyl-sulphonamido)- $N$-hydroxy-3-methylbutana mide) derivative [49], and ${ }^{11} \mathrm{C}$-labelled counterpart of CGS27023A [107], for tumor imaging. In a PET study of vessel inflammation, Hartung et al. [108] used 124I-HO-MIP (CGS 27023A) in ApoE-/- mice after carotid ligation following a high-cholesterol diet. Intense tracer uptake in the carotid lesion was detected from microPET images, indicating increased local MMP activity (Figure 5). The imaging results were in accordance with histology and immunohistochemistry for MMP expression. In another study [103], ${ }^{18} \mathrm{~F}-\mathrm{MMPI}$ was used in $\mathrm{ApoE} / \mathrm{-}$ mice on a high-cholesterol diet. Ex vivo PET/CT shows MMP-positive plaques in the inner curvature of the aorta.

\subsubsection{IL-2}

Interleukin (IL)-2 is a small single-chain glycoprotein $(15.5 \mathrm{kDa})$ of 133 amino acids synthesized and secreted by activated $\mathrm{T}$ lymphocytes, especially $\mathrm{CD} 4^{+}$ and $\mathrm{CD}^{+}$Th1 lymphocytes. T lymphocyte activation is seen in many types of inflammatory diseases, such as inflammatory degenerative diseases, graft rejection, tumor inflammation, organ-specific autoimmune diseases, and adipose inflammatory insulin resistance [109]. IL-2 binds with high affinity to the cell membrane IL-2 receptor, which is mainly expressed on the cell surface of activated T lymphocytes. PET imaging of activated $\mathrm{T}$ lymphocytes by radiolabeled IL-2 therefore provides an in vivo, dynamic approach in studying the immune-cell infiltration in these inflammatory diseases. Previously, ${ }^{123} \mathrm{I}$ and $99 \mathrm{mTc}$ labeled IL-2 have been used in many chronic inflammatory diseases, such as autoimmune diseases [110], coeliac disease [111], and vulnerable atherosclerotic plaques [112] via SPECT imaging. However, routine application of this technique was limited because the labeling procedures is complex and the spatial resolution of SPECT is not high enough. Recently, Gialleonardo et al. reported the labeling of IL-2 with $N$-succinimidyl $4-{ }^{18} \mathrm{~F}-$ fluorobenzoate $\left({ }^{18} \mathrm{~F}-\mathrm{SFB}\right)$ for the synthesis of ${ }^{18} \mathrm{~F}-\mathrm{FB}-\mathrm{IL}-2$ to detect activated $\mathrm{T}$ lymphocytes in inflammation [113]. In one of their studies, SCID mice were inoculated with phytohemagglutinin-activated human peripheral blood mononuclear cells (hPBMc) in Matrigel on the right flank while only Matrigel was injected as control on the left. At 60-90 min after cell inoculation, PET imaging found that ${ }^{18} \mathrm{~F}-\mathrm{FB}-\mathrm{IL}-2$ could detect the implanted hPBMc on the right flank. However, the control side also showed tracer uptake, mainly around the Matrigel site. The authors claimed that it was probably due to the migration of hPBMc from right side to left as a result of Matrigel induced inflammation. They also performed a dynamic PET study in Wistar rats with xenografted hPBMC [114]. Tracer accumulation to activated T cells was clearly observed and the kinetics of ${ }^{18} \mathrm{~F}-\mathrm{FB}-\mathrm{IL}-2$ in 
an inflammatory lesion could be described by Logan graphical analysis and compartment modeling. These pilot studies suggest that ${ }^{18} \mathrm{~F}-\mathrm{FB}-\mathrm{IL}-2$ is stable, biologically active, and allows for in vivo detection of activated $\mathrm{T}$ lymphocytes.

\subsubsection{TNF- $\alpha$}

Tumor necrosis factor- $\alpha$ (TNF- $\alpha$ ) is a cytokine that can contribute to cell apoptosis and organ dysfunction [115]. In the early phase of inflammation, TNF-a increases the transport of white blood cells to the inflammation sites. In the late phase, TNF-a level is lowered and can cause the apoptosis of inflammatory cells to terminate further unnecessary inflammation. Many studies show that TNF-a is important in acute immune response to infection, injury, autoimmune and chronic inflammatory disorders such as rheumatoid arthritis [15] and psoriasis [14]. Previ- ously, our group used a PET tracer ${ }^{64} \mathrm{Cu}$-DOTA-etanercept, to image acute inflammatory process induced by 12-O-tetradecanoylphorbol13-acetate (tetradecanoyl phorbol acetate, TPA) [116]. MicroPET imaging showed high ${ }^{64} \mathrm{Cu}$-DOTAetanercept uptake in the inflamed ear only during the early acute inflammatory phase but not the chronic inflammation phase, indicating that TNF-a contributes to the onset of acute inflammation (Figure 6, left). This imaging trend was confirmed by ex vivo enzyme-linked immunosorbent assay (ELISA) assay of TNF-a levels in the inflamed ears. Gao et al. synthesized ${ }^{11} \mathrm{C}$-labeled tricyclic Nec-3 necroptosis inhibitor 3,3a,4,5-tetrahydro-2H-benz $[g]$ indazoles as a potential PET tracer for imaging TNF-a, but without in vivo evaluation [117].
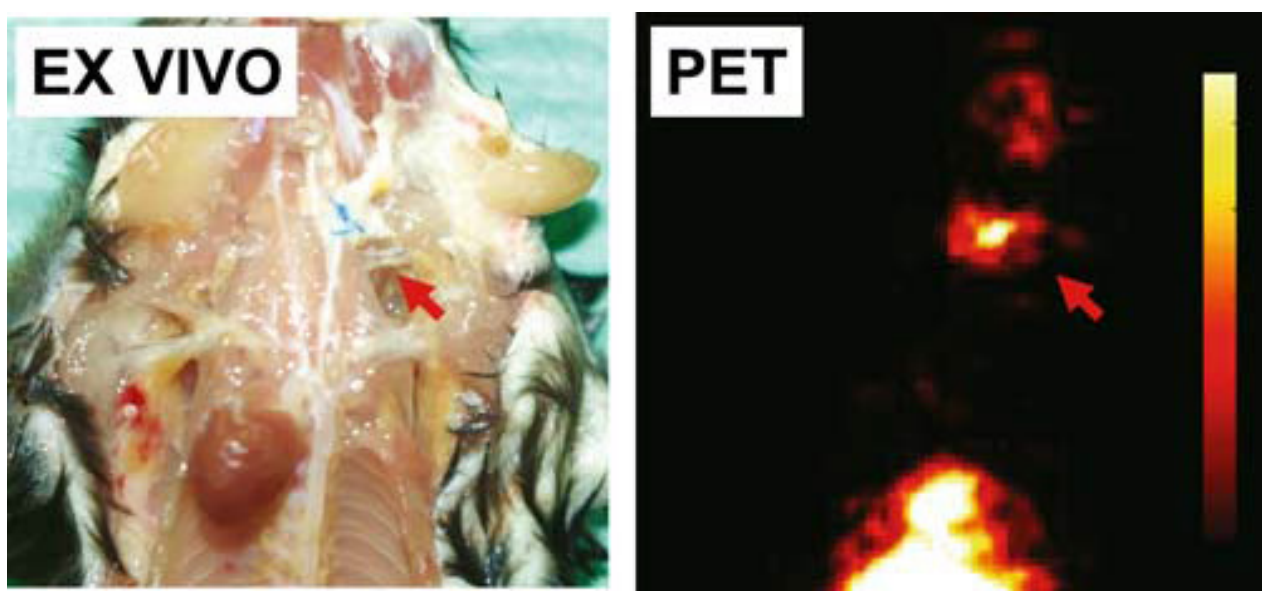

Figure 5. Site of ligated left common carotid artery (left panel) and a corresponding whole body coronal slice ( $0.4 \mathrm{~mm}$ thick) through a left carotid lesion (right panel) 4 weeks after ligation and a high cholesterol diet in an apoE ${ }^{-1-}$ mouse. Intense uptake of the radiolabeled broad spectrum MMP inhibitor ${ }^{124}$ I-HO-MPI in the left carotid lesion (arrow) $30 \mathrm{~min}$ after intravenous injection is visible using high-resolution small animal PET (Hartung, 2007 [108]).

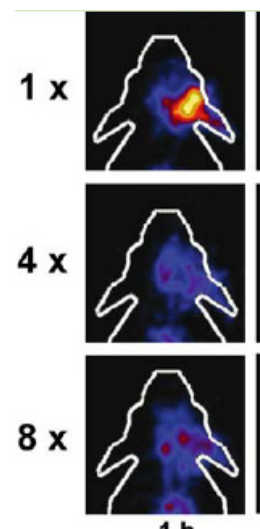

$1 \mathrm{~h}$
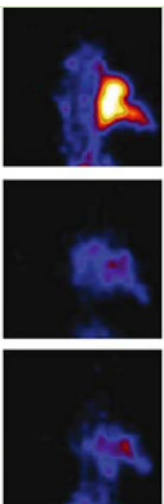

$4 \mathrm{~h}$
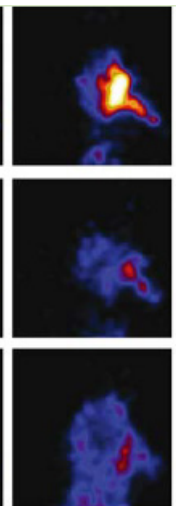

$16 \mathrm{~h}$
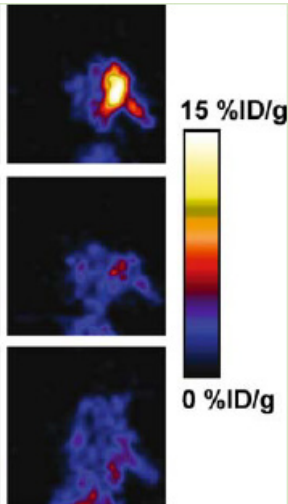

$24 \mathrm{~h}$
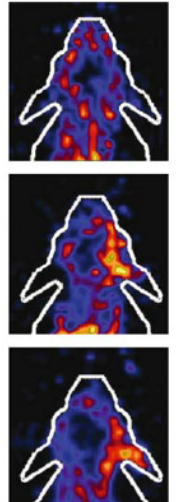

$1 \mathrm{~h}$
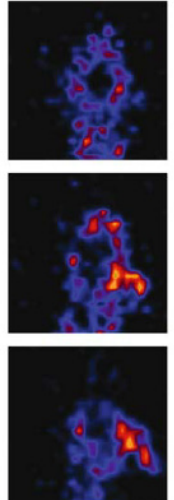

$4 \mathrm{~h}$

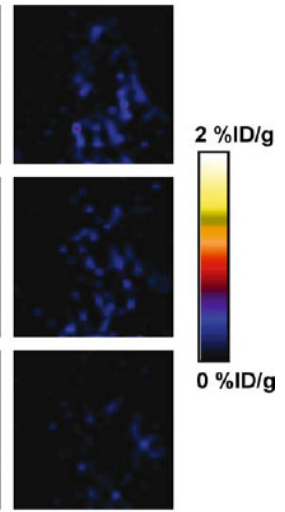

Block

Figure 6. MicroPET imaging using ${ }^{64} \mathrm{Cu}$-DOTA-etanercept (left) and ${ }^{64} \mathrm{Cu}-\mathrm{DOT} A-\mathrm{RGD}$ (right) of mouse right ear subjected to TPA challenge at various times. ${ }^{64} \mathrm{Cu}$-DOTA-etanercept showed intensive ear uptake only in acute inflammation phase, while ${ }^{64} \mathrm{Cu}-\mathrm{DOTA}-\mathrm{RGD}$ showed chronic inflammatory ear uptake (Cao, 2007 [II6]). 


\subsection{Targets on inflammation related vessels}

\subsection{Integrin receptor}

Integrin $\alpha_{v} \beta_{3}$, a cell adhesion molecule, is overexpressed in various cancer cells [118], endothelial cells of neovessels [119], and also in some inflammatory cells such as macrophages $[120,121]$. The study of integrin $\alpha_{v} \beta_{3}$ in cancers and tumor related angiogenesis has been extensively investigated in the past two decades [122-124]. RGD peptides containing the three amino acid sequence Arg-Gly-Asp, are av $\beta 3$ specific ligands. Radiolabeled RGD peptides have been successfully tested in the clinic [125], complementing conventional FDG imaging. Recently, some chronic inflammatory conditions with inflammatory angiogenesis, such as inflammatory bowel disease [126] and rheumatoid arthritis [127], also showed the participation of integrin av $\beta 3$ in the inflammatory neovessels in disease etiology and progression. Therefore, integrin av $\beta 3$ emerges as a target for inflammation therapy as well as molecular imaging. Actually, studies on av $\beta 3$ targeted treatment have shown success in several inflammatory diseases [127, 128]. Several PET studies of inflammatory processes using radiolabeled RGD peptides have also been reported. Pichler et al. [129] used ${ }^{125}$ I-gluco-RGD and ${ }^{18}$ F-gluco-RGD to study 2,4,6-trinitrochlorobenzene (TNCB) induced delayed-type hypersensitivity reaction (DTHR) model of inflammation and found chronic but not acute inflammatory ear had intensive tracer uptake, which could be further blocked by pre-injection of cold RGD. The imaging result was verified by histology and immunohistochemistry of av $\beta 3$ expression in the inflammatory foci. These findings echo what we observed in acute and chronic ear inflammation models using a different $\operatorname{av} \beta 3$ radioligand, $\left.{ }^{64} \mathrm{Cu}-\mathrm{DOTA}-\mathrm{E}[\mathrm{c}(\mathrm{RGDyK})]_{2}\right\}_{2}$ [116] (Figure 6, right). Both studies suggest that radiolabeled RGD peptides can reflect the angiogenesis during chronic inflammatory process.

In addition to imaging inflammatory angiogenesis, using RGD peptide in atherosclerosis imaging also came with positive results. Laitinen et al. [130] found ${ }^{18} \mathrm{~F}-$-Galacto-RGD accumulation in atherosclerotic lesions of mouse aorta by small animal PET/CT, and the high tracer uptake was associated with macrophage density revealed by histology study. In another study using hypercholesterolemic LDLR-$A p o B^{100 / 100}$ mice, the same group investigated the effect of lipid-lowering diet on plaque formation. They found that ${ }^{18} \mathrm{~F}$-galacto-RGD uptake in the aorta from regular food group is significantly lower than that from the high-fat diet group, indicating lipid-lowering diet could decrease the formation of atherosclerosis. Overexpression of $\alpha_{v}$ and $\beta_{3}$ integrins on macrophages in the aorta was confirmed by flow cytometry [131]. Still others used ${ }^{68} \mathrm{Ga}$-DOTA-RGD to image plaques ex vivo to measure the degree of inflammation and the vulnerability of atherosclerotic plaques [132]. Autoradiography showed significantly higher uptake of ${ }^{68} \mathrm{Ga}$-DOTA-RGD in plaques as compared to the healthy vessel wall and adventitia. However, there was no significant difference in aorta tracer uptake compared to control mice, which was probably due to the tissues around the healthy vessel wall, and the overall low uptake of the tracer in therosclerotic plaques. Therefore, further studies are needed to determine the validity of RGD peptide tracers to image arterial plaques in human.

\subsubsection{VAP-I}

Vascular adhesion protein 1 (VAP-1) is an endothelial adhesion protein stored in intracellular granules within endothelial cells. The expression of VAP-1 is quite low on the endothelial surface of normal tissues. Upon stimulation, VAP-1 is translocated onto the luminal surface of endothelial cells at sites of inflammation, causing the migration of leukocytes, especially $\mathrm{CD}^{+} \mathrm{T}$ lymphocytes, from the blood into the non-lymphoid inflammatory foci [133]. VAP-1 is, therefore, a promising target for both anti-inflammation therapy and molecular imaging of inflammation. A number of studies using radiolabeled synthetic peptides have been attempted to image VAP-1 expression [24, 134-137]. These ligands were either designed by molecular modeling based on the crystal structure of human VAP-1 or selected from phage display libraries and were labeled with ${ }^{68} \mathrm{Ga}$ to form ${ }^{68} \mathrm{Ga}$-DOTA-Siglec-9 [136], ${ }^{68} \mathrm{Ga}-D O T A V A P-P 1$ [24, 137], ${ }^{68} \mathrm{Ga}-D O T A V A P-P E G-P 1 \quad[134], \quad$ or ${ }^{68} \mathrm{Ga}-D O T A V A P-P E G-P 2$ [135]. These VAP-1 targeted PET tracers have been tested in sterile/infectious inflammatory and tumor-bearing animal models. In one study, ${ }^{68}$ Ga-DOTAVAP-P1 was compared with ${ }^{18} \mathrm{~F}-\mathrm{FDG}$ to differentiate turpentine oil induced muscular inflammation and human BxPC3 xenografted tumors [24]. PET with ${ }^{68} \mathrm{Ga}$-DOTAVAP-P1 showed intensive inflammatory foci uptake, concordant with the high VAP-1 expression examined by ex vivo studies. However, ${ }^{68} \mathrm{Ga}-\mathrm{DOTAVAP}-\mathrm{P} 1 \mathrm{had}$ very low uptake in BXPC3 tumors (Figure 7), suggesting the ability of this tracer to tell inflammation from tumor. In contrast, FDG showed high uptake in both inflammation foci and tumors, unable to discriminate one from the other. ${ }^{68} \mathrm{Ga}$-DOTAVAP-P1 has also been used to image osteomyelitic bones [138] and differentiate osteomyelitic bones from inflammation in healing bones [137]. In the differentiation study in particular, rat 
model of healing cortical bone defects (representing the sterile inflammation process of bone healing) and bone osteomyelitis were compared using ${ }^{68} \mathrm{Ga}$-DOTAVAP-P1 PET. At day 7 after operation, the sterile inflammation in healing cortical bone defect showed a significant decrease in tracer uptake, while osteomyelitis uptake of ${ }^{68} \mathrm{Ga}$-DOTAVAP-P1 remained high. This study showed the potential of ${ }^{68} \mathrm{Ga}$-DOTAVAP-P1 to differentiate bacterial infection from nonbacterial inflammation.
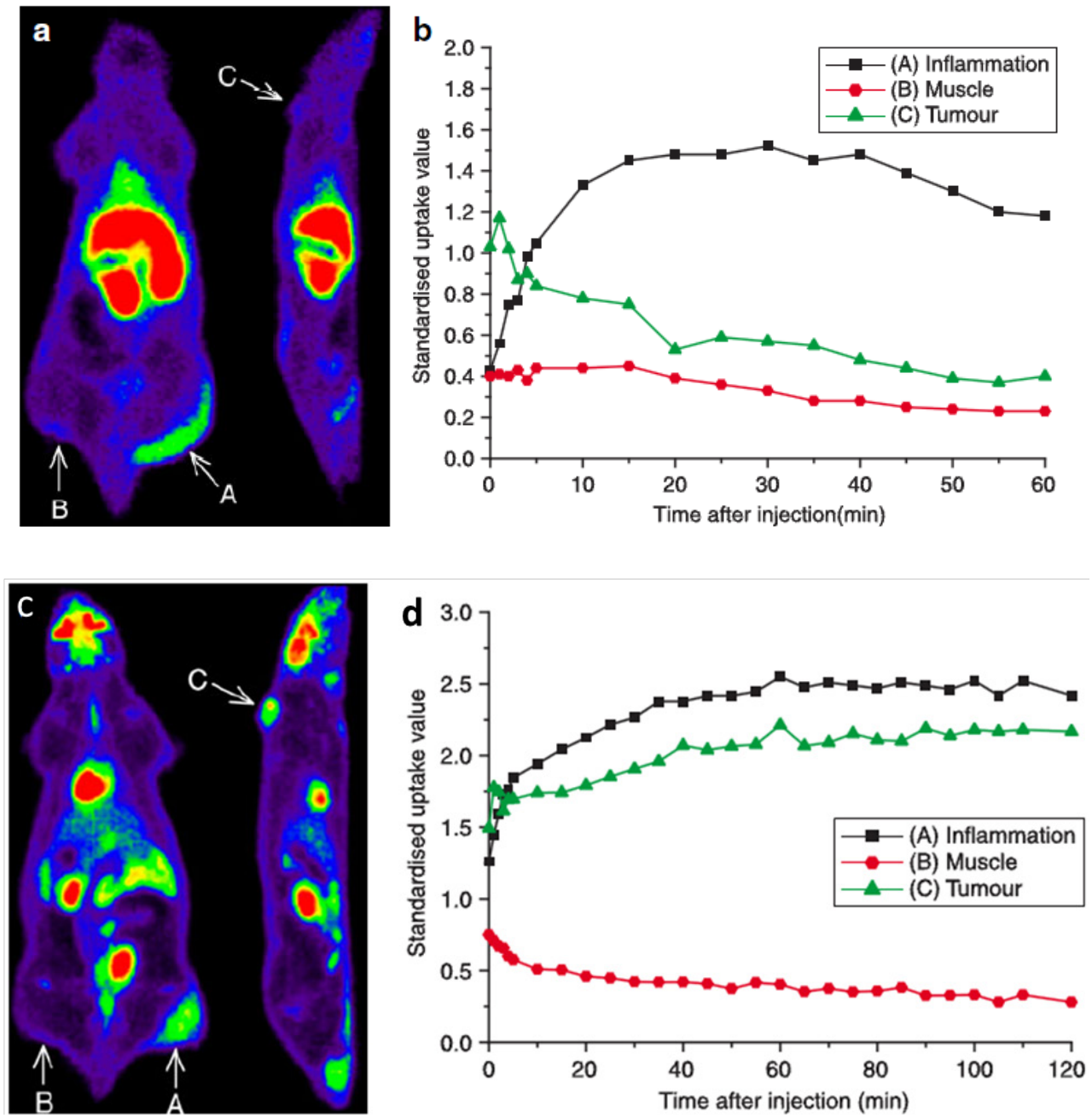

Figure 7. ${ }^{68} \mathrm{Ga}-\mathrm{DOTAVAP}-\mathrm{PI}(\mathrm{a}, \mathrm{b})$ and ${ }^{18} \mathrm{~F}-\mathrm{FDG}$ (c, d) PET imaging of mice with BxPC-3 tumor inoculation and turpentine induced inflammation. (a) ${ }^{68} \mathrm{Ga}$-DOTAVAP-PI uptake is clearly seen at the site of inflammation (arrow A) but not in the muscle (arrow B) or the tumor (arrow C). (b) Time-activity curve (TAC) of ${ }^{68} \mathrm{Ga}$-DOTAVAP-PI uptake in the inflammation site, muscle and tumor. (c) ${ }^{18} \mathrm{~F}-\mathrm{FDG}$ uptake is clearly seen at the site of inflammation (arrow A) as well as the tumor (arrow C). (d) TAC of ${ }^{18} \mathrm{~F}-\mathrm{FDG}$ uptake in the inflammation site, muscle, and tumor (Autio, 20I0 [24]).

\subsubsection{VCAM-I}

Vascular cell adhesion molecule (VCAM)- 1 is one member of the immunoglobulin superfamily of endothelial adhesion molecules. It plays an important role in all stages of atherosclerotic plaque $[139,140]$. It is expressed on activated endothelium and can induce the adhesion of macrophages at the early stage of plaque formation. A linear peptide affinity ligand, VHPKQHR, was identified using in vivo phage display in apolipoprotein E-deficient mice. This sequence is homologous to very late antigen- 4 , a known ligand for VCAM-1 [141]. A multivalent PET imaging agent $\left({ }^{18} \mathrm{~F}-4 \mathrm{~V}\right)$ has been developed based on this peptide sequence and applied to evaluate expression of VCAM-1. In (ApoE) $)^{-/-}$mice with atherosclerotic plaques located in the aortic root, PET images showed strong focal signal in the aortic root. Consistent with the imaging results, a high level of VCAM-1 mRNA was confirmed in the aortic sections. Also in this study, PET imaging using ${ }^{18} \mathrm{~F}-4 \mathrm{~V}$ was used for other cardiovascular disorders, such as myocardial infarction and transplant rejection with possible VCAM-1-mediated monocyte recruitment. Images 
showed ${ }^{18} \mathrm{~F}-4 \mathrm{~V}$ uptake in the infarcted left ventricular wall in the MI model mice and in the cardiac allograft models; the inflamed myocardium also showed high tracer uptake after transplanted cardiac allografts underwent rejection.

\subsubsection{Vessel permeability}

In normal conditions, vascular integrity is important in maintaining the homeostasis of the internal environment. Upon stimulation by various stimuli, as in acute inflammatory process, local vessel permeability is remarkably increased due to the release of many cytokines, chemokines, and leukotrienes by resident inflammatory cells and endothelial cells. This is important for self-defense by allowing immune cells such as neutrophils and macrophages to infiltrate into inflammatory foci. Therefore, either in sterile or infectious inflammation, increased vessel permeability could be utilized as a "biomarker" for inflammation imaging. Gallium ion has traditionally been used to image inflammation with gamma cameras. The accumulation of ${ }^{67} \mathrm{Ga}$ in inflammation foci can be explained either by binding to transferrin then diffusing into sites of inflammation via increased vascular permeability, or by binding to local lactoferrin produced by leucocytes, or siderophores produced by infecting micro-organisms [142]. However, the disadvantages of ${ }^{67} \mathrm{Ga}$ limit its wide-spread applicationz, such as high cost, long half-life $(3.26 \mathrm{~d})$ and poor imaging quality due to its wide spectrum of gamma rays emitted. ${ }^{68} \mathrm{Ga}$ has the same chemical characteristics as ${ }^{67} \mathrm{Ga}$, but with easier production procedure, short half-life $(68 \mathrm{~min})$ and positron-emitting property, therefore making it a better alternative for inflammation PET imaging. In fact, ${ }^{68} \mathrm{Ga}$ is now in clinical trials for imaging infectious bone [143] and non-infectious bone defect healing process [144]. In these studies, infectious inflammatory bones showed high uptake of ${ }^{68} \mathrm{Ga}$ or ${ }^{68} \mathrm{Ga}$-citrate, while animal models of bone defect without infection did not show very significant local ${ }^{68} \mathrm{Ga}$ uptake. Although local vessel permeability is increased under both conditions, the authors suggested that this might due to the binding of ${ }^{68} \mathrm{Ga}$ to the siderophores produced by micro-organisms which did not exist in the sterile inflammation. Therefore infectious bone had higher ${ }^{68} \mathrm{Ga}$ uptake than the non-infectious bone defect. Consequently, it is reasonable to assume that ${ }^{8} \mathrm{Ga}$ PET will be more valuable than conventional ${ }^{18} \mathrm{~F}-\mathrm{FDG}$ imaging in lowering the odds of false-positive findings in post-surgical and post-traumatic bone healing [144].

${ }^{68} \mathrm{Ga}$ has also been used to image atherosclerotic inflammation in animal models [12]. Intensive atherosclerosis uptake of ${ }^{8} \mathrm{Ga}$ was observed in this study. The reasons for the accumulation in inflamed plaques, as the authors claimed, might be due to locally increased vessel permeability, competitive binding to the $\mathrm{Ca}^{2+}$ and $\mathrm{Mg}^{2+}$ in calcified areas or binding to the circulating transferrin and to the transferrin receptors at the site of atherosclerotic artery binding sites.

\section{Evaluation of inflammatory diseases using PET}

An increasing number of diseases have recently been found to be inflammation related, such as atherosclerosis [145], neurodegenerative disorders [146], and malignant tumors [147]. Non-invasive PET imaging has the potential to help figure out the mechanism of inflammatory disease processes, discover potential targeted therapeutics, and establish new diagnostic standards.

\section{I Cardiovascular inflammation: focusing on atherosclerosis}

As an inflammatory disease, the onset, progression, and destabilization of atherosclerosis involves multi-participants within the immune response, including activation of endothelial cells, infiltration of various cells, release of inflammatory cytokines, and macrophage apoptosis. Due to the high morbidity and mortality rates of atherosclerosis, early detection and full characterization of atherosclerosis is of extreme necessity. So far, ${ }^{18} \mathrm{~F}-\mathrm{FDG}$ is the most extensively used probe for atherosclerosis imaging [9, 13, 148, 149] (Table 1). Many preclinical and clinical studies have established the correlation not only between local FDG uptake and plaque macrophage density but also between high metabolic activities of macrophages within plaques and cardiovascular risk factors. However, the partial volume effect, high physiology uptake of ${ }^{18} \mathrm{~F}-\mathrm{FDG}$ in the myocardium or brain, and motion artifacts from cardiac movement all make visualization of small atherosclerotic plaques in these areas rather cumbersome. In fact, besides high glucose metabolism, many inflammation biomarkers have been evaluated for atherosclerosis PET imaging, including the aforementioned choline metabolism, TSPO, SSTR, VAP-1, MMPs, integrin receptors, and VCAM-1. Some of the PET probes, such as radio-labeled PK11195 (binding to TPSO), choline (targeting to the phosphatidylcholine catabolism of macrophages and monocytes), TATE/TOC (binding to SSTR), are superior to conventional ${ }^{18} \mathrm{~F}-\mathrm{FDG}$ in their low myocardium biodistribution. Consequently, the images achieved high target-to-background ratio, facilitating the analysis of small coronary plaques. In addition, PET imaging of MMPs could assess the plaque-promoting activity of macrophages rather than their density in vulnerable plaques, and integrin receptor targeted imaging could detect CD68-positive 
macrophages in the vulnerable plaques [120]. PET imaging of these biomarkers, together with other conventional angiography, opens up the opportunity for better diagnosis and prognosis of atherosclerosis.

\subsection{Neuroinflammation}

Recently, accumulating evidences have revealed that many chronic neuroinflammatory diseases are caused by activated microglia in the CNS [150]. As the resident immune cells in the CNS, microglial cells are activated in the acute neuroinflammation phase and protect brain tissue from further injury through migration, proliferation, and production of neurotoxic factors. However in chronic neuroinflammation, microglia activation causes long-term cerebral damage by inducing autoimmune reaction. The activation of microglia is observed in various CNS diseases such as stroke, multiple sclerosis, Alzheimer's disease, and Parkinson's disease [151]. Several known neuroinflammation related targets include TSPO, $\mathrm{CB}_{2} \mathrm{R}$, and COX-2. Among them, TSPO is the most popular target for PET imaging which has already undergone clinical application, while $\mathrm{CB}_{2} \mathrm{R}$ and $\mathrm{COX}-2$ are still in the preliminary stage as imaging targets (Table 3 ).

As for the clinical translation, although some limitations do exist, TPSO targeted PET imaging of neuroinflammatory disease has provided some helpful information in disease diagnosis and prognosis. For example, in AD patients, TPSO PET enabled the discovery of the relationship between $A \beta$ accumula- tion and microglia activation during disease process [152] and can detect an age related increase in microglia activation in normal human brains and in AD progression [153]. However, based on current research, no definite conclusion can be drawn between the results of amyloid plaque imaging using ${ }^{11} \mathrm{C}$-PIB and inflammation imaging targeting TPSO [53, 154, 155]. Microglia activation was found to be a potential driving force in the development of Parkinson's disease with dementia (PDD) and could be detected via TPSO PET at the early phase in PD patients [156]. In stroke, TSPO PET imaging was able to find the temporal dynamics of microglia activation in patients, which was correlated with clinical outcome [157]. In traumatic brain injury (TBI), the imaging of microglia via TSPO was found to be present up to 17 years after TBI, indicating the possible benefit of long-term interventions for post-TBI patients [158]. However, some discrepancies exist among different studies, and this might be due to the lack of standardized analysis of imaging results and certain limitations of radiotracer for PET neuroinflammation imaging, such as low binding affinity and low target-to-background ratio [159]. Therefore, the development of new tracers with better imaging properties and the improvement in quantitative data analysis should be of great importance for PET guided neuroinflammation imaging in the future.

Table 3. CNS diseases evaluated by PET targeting on inflammatory biomarkers.

\begin{tabular}{|c|c|c|c|c|c|}
\hline Disease Type & Imaging target & Clinical / Preclinical & Imaging modality & Tracer & References \\
\hline \multirow[t]{2}{*}{$\begin{array}{l}\text { Traumatic brain injury } \\
\text { (TBI) }\end{array}$} & TSPO & Preclinical, rat & Animal PET & $\begin{array}{l}{ }^{18} \text { F-DAA1106, } \\
{ }^{11} \text { C-verapamil, } \\
{ }^{11} \text { C-PK11195 }\end{array}$ & $\begin{array}{l}\text { Yu, } 2010[160] \\
\text { Folkersma, 2011 [161] }\end{array}$ \\
\hline & TSPO & Clinical & PET, MRI & ${ }^{11} \mathrm{C}-\mathrm{PK} 11195$ & Ramlackhansingh, 2011 [158] \\
\hline \multirow[t]{2}{*}{ Cerebral ischemia } & TSPO & Preclinical, rat & PET, MRI & $\begin{array}{l}{ }^{18} \mathrm{~F}-\mathrm{DPA}-714 \\
{ }^{18} \mathrm{~F}-\mathrm{FEAC} \\
{ }^{18} \mathrm{~F}-\mathrm{FEDAC}\end{array}$ & $\begin{array}{l}\text { Martin, } 2010 \text { [162] } \\
\text { Yui, } 2010 \text { [52] }\end{array}$ \\
\hline & TSPO & Clinical & PET, MRI & $\begin{array}{l}{ }^{11} \text { C-vinpocetine } \\
{ }^{11} \text { C-Pk11195 }\end{array}$ & $\begin{array}{l}\text { Gulyás, } 2012 \text { [54] } \\
\text { Thiel, } 2010 \text { [157] }\end{array}$ \\
\hline \multirow[t]{2}{*}{ Multiple sclerosis (MS) } & TSPO & Preclinical, rat & Animal PET & ${ }^{11} \mathrm{C}-\mathrm{DAC}$ & Xie, 2012 [163] \\
\hline & TSPO & Clinical & PET, MRI & ${ }^{11} \mathrm{C}-\mathrm{PBR} 28$ & Oh, 2011 [45] \\
\hline \multirow[t]{3}{*}{$\begin{array}{l}\text { Alzheimer's Disease } \\
\text { (AD) }\end{array}$} & TSPO & Preclinical, mouse & Animal PET & $\begin{array}{l}{ }^{11} \mathrm{C}-\mathrm{AC}-5216 \\
{ }^{18} \mathrm{~F}-\mathrm{FEDAA1106}\end{array}$ & Maeda, 2011 [53] \\
\hline & TSPO & Clinical & PET, MRI & $\begin{array}{l}{ }^{11} \mathrm{C} \text {-vinpocetine } \\
{ }^{11} \mathrm{C}-\mathrm{PK} 11195\end{array}$ & $\begin{array}{l}\text { Gulyás, } 2011 \text { [153] } \\
\text { Yokokura, } 2011 \text { [152] }\end{array}$ \\
\hline & $\mathrm{CB}_{2} \mathrm{R}$ & Preclinical, mouse & animal PET & ${ }^{11} \mathrm{C}-\mathrm{A}-836339$ & Horti, 2010 [76] \\
\hline $\begin{array}{l}\text { Parkinson's Disease } \\
\text { (PD) }\end{array}$ & TSPO & Clinical & PET, MRI & 11C-PK11195 & $\begin{array}{l}\text { Gerhard, } 2006 \text { [164] } \\
\text { Edison, } 2012 \text { [156] }\end{array}$ \\
\hline $\begin{array}{l}\text { Huntington's } \\
\text { disease (HD) }\end{array}$ & TSPO & Clinical & PET, MRI & $\begin{array}{l}{ }^{11} \mathrm{C}-\mathrm{PK} 11195 \\
{ }^{11} \mathrm{C} \text {-raclopride }\end{array}$ & Politis, 2011 [165] \\
\hline Epilepsy & TSPO & Clinical (one case) & PET, MRI & ${ }^{11} \mathrm{C}-\mathrm{PK} 11195$ & Dedeurwaerdere, 2012 [51] \\
\hline Brain inflammation & $\operatorname{cox}$ & Preclinical, rat & Animal PET & $\begin{array}{l}{ }^{11} \mathrm{C}-\text { ketoprofen me- } \\
\text { thyl ester } \\
{ }^{11} \mathrm{C} \text {-rofecoxib }\end{array}$ & $\begin{array}{l}\text { Shukuri, } 2011 \text { [92] } \\
\text { de Vries, } 2008 \text { [91] }\end{array}$ \\
\hline
\end{tabular}




\subsection{Tumor related inflammation}

Inflammation contributes to a tumor's immune escape phenomenon, creating a proper environment for neoplastic onset and continued growth. In fact, inflammatory cells and mediators are present in the microenvironment of virtually all tumors that are not epidemiologically related to inflammation [166]. Recently, tumor-associated macrophages (TAMs) or tumor-infiltrating macrophages (TIMs) have been intensively investigated as a target for imaging and therapy [167]. TAMs enhance tumor cell migration and invasion through their secretion of chemotactic and chemokinetic factors [168]. Depletion of TAMs improved the effect of chemotherapy in some cancer models [169]. Therefore, TAMs targeted imaging would have great value providing guidance for macrophage targeted cancer therapy and patient stratification for personalized treatment. Various molecular imaging techniques have been applied to study TAMs, including MRI [170], optical imaging [171], PET [172], SPECT [173], and hybrid molecular imaging modality $[174,175]$, in which most of the imaging agents are nanomaterial based. Studies performed by Zheng et al. [176] using ${ }^{18} \mathrm{~F}-\mathrm{DPA}-714$, a TSPO specific tracer, proved that TSPO was positive in both breast cancer cells and TAMs. These results supported that TSPO expression inside tumors came from mixed cell populations, leading the way for future development of imaging and therapeutic ligands targeting TSPO on macrophages. In another study, Locke et al. [82] performed PET imaging of TAMs using mannose coated ${ }^{64} \mathrm{Cu}$ liposomes and showed that the imaging agent could accumulate in TAMs in a pulmonary adenocarcinoma foci in a mouse model.

Because FDG could also accumulate in non-neoplastic cells that infiltrate neoplasms [167], without histological validation, it remains unclear what percentage of FDG accumulation is caused by peritumoral and intratumoral inflammation. Hence, it is a consensus in clinical setting that cancer therapy evaluation using FDG PET should be carefully conducted, especially when effective treatment can lead to massive inflammation. Consequently, many studies focused on developing more tumor cell specific PET tracers beyond FDG. Some tumor proliferation markers such as lipid precursors, amino acids, nucleosides, and receptor ligands have been tested for this purpose. For example, ${ }^{11} \mathrm{C}$-choline was developed to evaluate intracellular choline kinase activity, ${ }^{11} \mathrm{C}$-methionine (MET) to image amino acid transporter, and ${ }^{18} \mathrm{~F}$-fluorothymidine (FLT) to determine thymidine kinase 1 activity [177]. In a preclinical study, Lee et al. [178] examined ${ }^{18}$ F-FET and ${ }^{18} \mathrm{~F}-\mathrm{FLT}$ along with ${ }^{18} \mathrm{~F}-\mathrm{FDG}$ to differentiate tumor from in- flammation. They found ${ }^{18} \mathrm{~F}-\mathrm{FET}$ and ${ }^{18} \mathrm{~F}-\mathrm{FLT}$ selectively localized in tumor tissues but not inflammation. Similar results were also reported elsewhere [179, 180]. Clinical studies also demonstrated that ${ }^{18} \mathrm{~F}-\mathrm{FLT}$ is significantly better than ${ }^{18} \mathrm{~F}-\mathrm{FDG}$ as a measure of tumor proliferation and more specific than ${ }^{18} \mathrm{~F}-\mathrm{FDG}$ PET for cancer staging. However, tumor uptake of ${ }^{18} \mathrm{~F}-\mathrm{FLT}$ is much less than ${ }^{18} \mathrm{~F}-\mathrm{FDG}$, resulting in a significantly lower sensitivity for ${ }^{18} \mathrm{~F}-\mathrm{FLT}$ PET than for ${ }^{18}$ F-FDG PET [181].

Several inflammation biomarkers may be promising in differentiating tumor from inflammation including VAP-1 and integrins. As mentioned before, the VAP-1 targeted peptidic tracer, ${ }^{68} \mathrm{Ga}-D O T A V A P-P 1$, showed accumulation in inflammation foci but not as much in tumors, making it a potential inflammation-targeting tracer [24]. ${ }^{18} \mathrm{~F}-\mathrm{FPPRGD} 2$, an integrin receptor targeting probe, was found to be superior to ${ }^{18} \mathrm{~F}-\mathrm{FDG}$ in monitoring tumor response to Abraxane treatment, possibly due to less uptake in TAM [182]. Admittedly, it is very challenging to develop an imaging probe which can separate tumor and inflammation completely since inflammation is an inherent tumor microenvironment.

\section{Conclusion and perspectives}

The process of inflammation is involved, either directly or indirectly in various human diseases, including stroke, Alzheimer's disease, atherosclerosis, autoimmune diseases, and even malignant disorders. Therefore, information extracted from molecular imaging of inflammation in these disorders is definitely helpful in disease diagnosis, and prognosis, therapy response monitoring, and shedding light on understanding the nature of disease processes. So far, many inflammation related biomarkers have been identified and investigated as imaging or therapy targets, including inflammatory cell metabolism, membrane markers, cytokines, and vascular changes during inflammation. After intensive preclinical studies, some of these targets have been tested in humans. For example, FDG PET has been used to evaluate inflammation in atherosclerosis plaques, and many new tracers in proof-of-concept clinical studies showed promise in discerning inflammation from background. To evaluate neuroinflammation in AD, PD, and ischemic neural diseases, PET imaging of TSPO expression on activated microglia showed very promising results. For tumor related inflammation imaging, tumor-associated macrophages become widely explored targets. In the never-ending debate on differentiating tumor from inflammation, a variety of PET probes have been studied. However, very few 
of them are considered to be inflammation specific. With better understanding of the inflammatory reaction in each disease type, more sensitive and specific biomarkers will be identified, and potential new imaging probes may be developed to target these biomarkers. Moreover, multiplexed imaging with tracers targeting different biomarkers and multimodal imaging by incorporating PET with other imaging modalities will also contribute to improved visualization and quantification of the inflammatory diseases.

\section{Acknowledgement}

This work was supported by the Intramural Research Program (IRP) of the National Institute of Biomedical Imaging and Bioengineering (NIBIB), National Institutes of Health (NIH).

\section{Competing Interests}

The authors have declared that no competing interest exists.

\section{References}

1. Chen CJ, Kono H, Golenbock D, Reed G, Akira S, Rock KL. Identification of a key pathway required for the sterile inflammatory response triggered by dying cells. Nat Med. 2007; 13: 851-6. doi:10.1038/nm1603.

2. Rock KL, Latz E, Ontiveros F, Kono H. The sterile inflammatory response. Annu Rev Immunol. 2010; 28: 321-42. doi:10.1146/annurev-immunol-030409-101311.

3. Chen GY, Nuñez G. Sterile inflammation: sensing and reacting to damage. Nat Rev Immunol. 2010; 10: 826-37. doi:10.1038/nri2873.

4. Krishnamoorthy S, Honn KV. Inflammation and disease progression. Cancer Met Rev. 2006; 25: 481-91. doi:10.1007/s10555-006-9016-0.

5. Mankoff DA. A definition of molecular imaging. J Nucl Med. 2007; 48: 18-21.

6. Weissleder R, Pittet MJ. Imaging in the era of molecular oncology. Nature. 2008; 452: 580-9. doi:10.1038/nature06917.

7. Emelianov SY, Li PC, O'Donnell M. Photoacoustics for molecular imaging and therapy. Phys Today. 2009; 62: 34-9.

8. Saraste A, Nekolla SG, Schwaiger M. Cardiovascular molecular imaging: an overview. Cardiovasc Res. 2009; 83: 643-52. doi:10.1093/cvr/cvp209.

9. Rosenbaum D, Millon A, Fayad ZA. Molecular imaging in atherosclerosis: FDG PET. Curr Atheroscler Rep. 2012; 14: 429-37. doi:10.1007/s11883-012-0264-x.

10. Chaudhari AJ, Bowen SL, Burkett GW, Packard NJ, Godinez F, Joshi AA, et al. High-resolution ${ }^{18} \mathrm{~F}-\mathrm{FDG}$ PET with MRI for monitoring response to treatment in rheumatoid arthritis. Eur J Nucl Med Mol Imaging. 2010; 37: 1047. doi:10.1007/s00259-009-1364-x.

11. Li X, Samnick S, Lapa C, Israel I, Buck AK, Kreissl MC, et al. ${ }^{68} \mathrm{Ga}$-DOTATATE PET/CT for the detection of inflammation of large arteries: correlation with $18 \mathrm{~F}-\mathrm{FDG}$, calcium burden and risk factors. EJNMMI Res. 2012; 2: 52. doi:10.1186/2191-219X-2-52.

12. Silvola JM, Laitinen I, Sipila HJ, Laine VJ, Leppanen P, Yla-Herttuala S, et al. Uptake of ${ }^{68}$ Gallium in atherosclerotic plaques in LDLR-/-ApoB100/100 mice. EJNMMI Res. 2011; 1: 14. doi:10.1186/2191-219X-1-14.

13. Yarasheski KE, Laciny E, Overton ET, Reeds DN, Harrod M, Baldwin S, et al. ${ }^{18}$ FDG PET-CT imaging detects arterial inflammation and early atherosclerosis in HIV-infected adults with cardiovascular disease risk factors. J Inflamm (Lond). 2012; 9: 26. doi:10.1186/1476-9255-9-26.

14. Bissonnette R, Tardif JC, Harel F, Pressacco J, Bolduc C, Guertin MC. Effects of the TNF alpha antagonist Adalimumab on arterial inflammation assessed by positron emission tomography in patients with psoriasis: Results of a randomized controlled trial. Circ Cardiovasc Imaging. 2013; 6: 83-90. doi:10.1161/CIRCIMAGING.112.975730.

15. Maki-Petaja KM, Elkhawad M, Cheriyan J, Joshi FR, Ostor AJ, Hall FC, et al. Anti-tumor necrosis factor-alpha therapy reduces aortic inflammation and stiffness in patients with rheumatoid arthritis. Circulation. 2012; 126 : 2473-80. doi:10.1161/CIRCULATIONAHA.112.120410.

16. Tegler G, Ericson K, Sorensen J, Bjorck M, Wanhainen A. Inflammation in the walls of asymptomatic abdominal aortic aneurysms is not associated with increased metabolic activity detectable by 18-fluorodeoxglucose positron-emission tomography. J Vasc Surg. 2012; 56: 802-7. doi:10.1016/j.jvs.2012.02.024.

17. Tezuka D, Haraguchi G, Ishihara T, Ohigashi H, Inagaki H, Suzuki J, et al. Role of FDG PET-CT in Takayasu arteritis: sensitive detection of recurrences. JACC Cardiovasc Imaging. 2012; 5: 422-9. doi:10.1016/j.jcmg.2012.01.013.

18. Sarda-Mantel L, Alsac JM, Boisgard R, Hervatin F, Montravers F, Tavitian B, et al. Comparison of $18 \mathrm{~F}$-fluoro-deoxy-glucose, 18F-fluoro-methyl-choline, and 18F-DPA714 for positron-emission tomography imaging of leukocyte accumulation in the aortic wall of experimental abdominal aneurysms. J Vasc Surg. 2012; 56: 765-73. doi:10.1016/j.jvs.2012.01.069.

19. Kim TN, Kim S, Yang SJ, Yoo HJ, Seo JA, Kim SG, et al. Vascular inflammation in patients with impaired glucose tolerance and type 2 diabetes: analysis with $18 \mathrm{~F}$-fluorodeoxyglucose positron emission tomography. Circ Cardiovasc Imaging. 2010; 3: 142-8. doi:10.1161/CIRCIMAGING.109.888909.

20. Dweck MR, Jones C, Joshi NV, Fletcher AM, Richardson H, White A, et al. Assessment of valvular calcification and inflammation by positron emission tomography in patients with aortic stenosis. Circulation. 2012; 125: 76-86. doi:10.1161/CIRCULATIONAHA.111.051052.

21. Irmler IM, Opfermann T, Gebhardt P, Gajda M, Brauer R, Saluz HP, et al. In vivo molecular imaging of experimental joint inflammation by combined 18 F-FDG positron emission tomography and computed tomography. Arthritis Res Ther. 2010; 12: R203. doi:10.1186/ar3176.

22. Yamashita H, Kubota K, Takahashi $Y$, Minamimoto R, Morooka M, Kaneko H, et al. Similarities and differences in fluorodeoxyglucose positron emission tomography/computed tomography findings in spondyloarthropathy, polymyalgia rheumatica and rheumatoid arthritis. Joint Bone Spine. 2013; 80: 171-7. doi:10.1016/j.jbspin.2012.04.006.

23. McLarty K, Moran MD, Scollard DA, Chan C, Sabha N, Mukherjee J, et al. Comparisons of [18F]-1-deoxy-1-fluoro-scyllo-inositol with [18F]-FDG for PET imaging of inflammation, breast and brain cancer xenografts in athymic mice. Nucl Med Biol. 2011; 38: 953-9. doi:10.1016/j.nucmedbio.2011.02.017.

24. Autio A, Ujula T, Luoto P, Salomaki S, Jalkanen S, Roivainen A. PET imaging of inflammation and adenocarcinoma xenografts using vascular adhesion protein 1 targeting peptide ${ }^{68 \mathrm{Ga}-D O T A V A P-P 1:}$ comparison with 18F-FDG. Eur J Nucl Med Mol Imaging. 2010; 37: 1918-25. doi:10.1007/s00259-010-1497-y.

25. Brown TL, Spencer HJ, Beenken KE, Alpe TL, Bartel TB, Bellamy W, et al. Evaluation of dynamic [ $\left.{ }^{18} \mathrm{~F}\right]-F D G-P E T$ imaging for the detection of acute post-surgical bone infection. PloS One. 2012; 7: e41863. doi:10.1371/journal.pone.0041863.

26. Lee WW, Marinelli B, van der Laan AM, Sena BF, Gorbatov R, Leuschner $F$, et al. PET/MRI of inflammation in myocardial infarction. J Am Coll Cardiol. 2012; 59: 153-63. doi:S0735-1097(11)04600-6 [pii]10.1016/j.jacc. 2011.08.066.

27. Rosenbaum SI, Lind T, Antoch G, Bockisch A. False-positive FDG PET uptake--the role of PET/CT. Eur Radiol. 2006; 16: 1054-65. doi:10.1007/s00330-005-0088-y.

28. Buscombe J, Signore A. FDG-PET in infectious and inflammatory disease. Eur J Nucl Med Mol Imaging. 2003; 30: 1571-3. doi:10.1007/s00259-003-1360-5.

29. Basu S, Zhuang H, Torigian DA, Rosenbaum J, Chen W, Alavi A. Functional imaging of inflammatory diseases using nuclear medicine techniques. Semin Nucl Med. 2009; 39: 124-45. doi:10.1053/j.semnuclmed.2008.10.006.

30. Mertens K, Slaets D, Lambert B, Acou M, De Vos F, Goethals I. PET with ${ }^{18} \mathrm{~F}-$ labelled choline-based tracers for tumour imaging: a review of the literature. Eur J Nucl Med Mol Imaging. 2010; 37: 2188-93. doi:10.1007/s00259-010-1496-z.

31. Jadvar H. Can Choline PET Tackle the challenge of imaging prostate cancer? Theranostics. 2012; 2: 331-2. doi:10.7150/thno.4288.

32. Schwarzenbock S, Souvatzoglou M, Krause BJ. Choline PET and PET/CT in primary diagnosis and staging of prostate cancer. Theranostics. 2012; 2: 318-30. doi:10.7150/thno.4008.

33. Picchio M, Castellucci P. Clinical indications of ${ }^{11} \mathrm{C}$-choline PET/CT in prostate cancer patients with biochemical relapse. Theranostics. 2012; 2: 313-7. doi:10.7150/thno.4007.

34. Matter CM, Wyss MT, Meier P, Spath N, von Lukowicz T, Lohmann C, et al. ${ }^{18} \mathrm{~F}$-choline images murine atherosclerotic plaques ex vivo. 
Arterioscler Thromb Vasc Biol. 2006; 26: 584-9. doi:10.1161/01.ATV.0000200106.34016.18.

35. Laitinen IE, Luoto P, Nagren K, Marjamaki PM, Silvola JM, Hellberg S, et al. Uptake of ${ }^{11} \mathrm{C}$-choline in mouse atherosclerotic plaques. J Nucl Med. 2010; 51: 798-802. doi:10.2967/jnumed.109.071704.

36. Bucerius J, Schmaljohann J, Bohm I, Palmedo H, Guhlke S, Tiemann K, et al. Feasibility of ${ }^{18} \mathrm{~F}$-fluoromethylcholine PET/CT for imaging of vessel wall alterations in humans--first results. Eur J Nucl Med Mol Imaging. 2008; 35: 815-20. doi:10.1007/s00259-007-0685-x.

37. Spaeth N, Wyss MT, Weber B, Scheidegger S, Lutz A, Verwey J, et al. Uptake of 18F-fluorocholine, 18F-fluoroethyl-L-tyrosine, and 18F-FDG in acute cerebral radiation injury in the rat: implications for separation of radiation necrosis from tumor recurrence. J Nucl Med. 2004; 45: 1931-8. doi:45/11/1931 [pii].

38. Roivainen A, Yli-Kerttula T. Whole-body distribution of ${ }^{11} \mathrm{C}$-choline and uptake in knee synovitis. Eur J Nucl Med Mol Imaging. 2006; 33: 1372-3. doi:10.1007/s00259-006-0184-5.

39. Bird JL, Izquierdo-Garcia D, Davies JR, Rudd JH, Probst KC, Figg N, et al. Evaluation of translocator protein quantification as a tool for characterising macrophage burden in human carotid atherosclerosis. Atherosclerosis. 2010; 210: 388-91. doi:10.1016/j.atherosclerosis. 2009.11.047.

40. Gaemperli O, Shalhoub J, Owen DR, Lamare F, Johansson S, Fouladi N, et al. Imaging intraplaque inflammation in carotid atherosclerosis with ${ }^{11}$ C-PK11195 positron emission tomography/computed tomography. Eur Heart J. 2012; 33: 1902-10. doi:10.1093/eurhearti/ehr367.

41. Hatori A, Yui J, Yamasaki T, Xie L, Kumata K, Fujinaga M, et al. PET imaging of lung inflammation with [18F]FEDAC, a radioligand for translocator protein $(18 \mathrm{kDa})$. PloS One. 2012; 7: e45065. doi:10.1371/journal.pone.0045065PONE-D-12-07784 [pii].

42. Hannestad J, Gallezot JD, Schafbauer T, Lim K, Kloczynski T, Morris ED, et al. Endotoxin-induced systemic inflammation activates microglia: $\left.{ }^{[11} \mathrm{C}\right]$ PBR28 positron emission tomography in nonhuman primates. NeuroImage. 2012; 63: 232-9. doi:10.1016/j.neuroimage.2012.06.055.

43. Roeda D, Kuhnast B, Damont A, Dollé F. Synthesis of fluorine-18-labelled TSPO ligands for imaging neuroinflammation with Positron Emission Tomography. J Fluor Chem. 2012; 134: 107-14. doi:10.1016/j.jfluchem.2011.03.020

44. Ching AS, Kuhnast B, Damont A, Roeda D, Tavitian B, Dolle F. Current paradigm of the $18-\mathrm{kDa}$ translocator protein (TSPO) as a molecular target for PET imaging in neuroinflammation and neurodegenerative diseases. Insights Imaging. 2012; 3: 111-9. doi:10.1007/s13244-011-0128-x.

45. Oh U, Fujita M, Ikonomidou VN, Evangelou IE, Matsuura E, Harberts E, et al. Translocator protein PET imaging for glial activation in multiple sclerosis. J Neuroimmune Pharmacol. 2011; 6: 354-61. doi:10.1007/s11481-010-9243-6.

46. Papadopoulos V, Lecanu L. Translocator protein (18 kDa) TSPO: an emerging therapeutic target in neurotrauma. Exp Neurol. 2009; 219: 53-7. doi:10.1016/j.expneurol.2009.04.016.

47. Gulyás B, Makkai B, Kása P, Gulya K, Bakota L, Várszegi S, et al. A comparative autoradiography study in post mortem whole hemisphere human brain slices taken from Alzheimer patients and age-matched controls using two radiolabelled DAA1106 analogues with high affinity to the peripheral benzodiazepine receptor (PBR) system. Neurochem Int. 2009; 54: 28-36. doi: 10.1016/j.neuint.2008.10.001.

48. Takashima-Hirano $\mathrm{M}$, Shukuri $\mathrm{M}$, Takashima $\mathrm{T}$, Goto $\mathrm{M}$, Wada $\mathrm{Y}$, Watanabe $\mathrm{Y}$, et al. General method for the ${ }^{11} \mathrm{C}$-labeling of 2-arylpropionic acids and their esters: construction of a PET tracer library for a study of biological events involved in COXs expression. Chemistry. 2010; 16: 4250-8. doi:10.1002/chem.200903044.

49. Wagner $\mathrm{S}$, Breyholz HJ, Holtke C, Faust A, Schober O, Schafers M, et al. A new 18F-labelled derivative of the MMP inhibitor CGS 27023A for PET: radiosynthesis and initial small-animal PET studies. Appl Radiat Isot. 2009; 67: 606-10. doi:10.1016/j.apradiso.2008.12.009S09698043(08)00554-X [pii].

50. Devinsky O, Vezzani A, Najjar S, De Lanerolle NC, Rogawski MA. Glia and epilepsy: excitability and inflammation. Trends Neurosci. 2013. doi:10.1016/j.tins.2012.11.008.

51. Dedeurwaerdere S, Callaghan PD, Pham T, Rahardjo GL, Amhaoul H, Berghofer P, et al. PET imaging of brain inflammation during early epileptogenesis in a rat model of temporal lobe epilepsy. EJNMMI Res. 2012; 2: 60. doi:10.1186/2191-219X-2-60.

52. Yui J, Maeda J, Kumata K, Kawamura K, Yanamoto K, Hatori A, et al. 18F-FEAC and 18F-FEDAC: PET of the monkey brain and imaging of translocator protein $(18 \mathrm{kDa})$ in the infarcted rat brain. J Nucl Med. 2010; 51: 1301-9. doi:jnumed.109.072223 [pii]10.2967/jnumed.109.072223.
53. Maeda J, Zhang MR, Okauchi T, Ji B, Ono M, Hattori S, et al. In vivo positron emission tomographic imaging of glial responses to amyloid-beta and tau pathologies in mouse models of Alzheimer's disease and related disorders. J Neurosci. 2011; 31: 4720-30. doi:10.1523/JNEUROSCI.3076-10.2011.

54. Gulyas B, Toth M, Schain M, Airaksinen A, Vas A, Kostulas K, et al. Evolution of microglial activation in ischaemic core and peri-infarct regions after stroke: a PET study with the TSPO molecular imaging

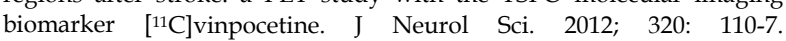
doi:10.1016/j.jns.2012.06.026.

55. Pugliese F, Gaemperli O, Kinderlerer AR, Lamare F, Shalhoub J, Davies $\mathrm{AH}$, et al. Imaging of vascular inflammation with $\left[{ }^{11} \mathrm{C}\right]-\mathrm{PK} 11195$ and positron emission tomography/computed tomography angiography. J Am Coll Cardiol. 2010; 56: 653-61. doi:10.1016/j.jacc.2010.02.063.

56. Lamare F, Hinz R, Gaemperli O, Pugliese F, Mason JC, Spinks T, et al. Detection and quantification of large-vessel inflammation with ${ }^{11} \mathrm{C}-(\mathrm{R})-\mathrm{PK} 11195 \quad$ PET/CT. J Nucl Med. 2011; 52: 33-9. doi:10.2967/jnumed.110.079038.

57. Hardwick MJ, Chen MK, Baidoo K, Pomper MG, Guilarte TR. In vivo imaging of peripheral benzodiazepine receptors in mouse lungs: a biomarker of inflammation. Mol Imaging. 2005; 4: 432-8.

58. Xie L, Yui J, Hatori A, Yamasaki T, Kumata K, Wakizaka H, et al. Translocator protein $(18 \mathrm{kDa})$, a potential molecular imaging biomarker for non-invasively distinguishing non-alcoholic fatty liver disease. J Hepatol. 2012; 57: 1076-82. doi:10.1016/j.jhep.2012.07.002S0168-8278(12)00529-6 [pii].

59. Maecke HR, Reubi JC. Somatostatin receptors as targets for nuclear medicine imaging and radionuclide treatment. J Nucl Med. 2011; 52: 841-4. doi:jnumed.110.084236 [pii]10.2967/jnumed.110.084236.

60. de Ruiter ED, Kwekkeboom DJ, Mooi WJ, Knegt P, Tanghe HL, van Hagen PM. Inflammatory pseudotumor of the fossa pterygopalatina: diagnosis and treatment. Neth J Med. 2000; 56: 17-20. doi:S0300297799001023 [pii].

61. Kwekkeboom DJ, van Hagen PM, Krenning EP. Refractory immune-mediated and haematological diseases: candidates for peptide receptor radiotherapy? Eur J Endocrinol. 2000; 143 Suppl 1: S53-6.

62. Kamphuis LSJ, Kwekkeboom DJ, van Laar JAM, van Daele PLA, Baarsma GS, van Hagen PM. Somatostatin receptor scintigraphy in sarcoidosis. J Transl Med. 2011; 9: P9.

63. Dalm VA, van Hagen PM, van Koetsveld PM, Achilefu S, Houtsmuller $\mathrm{AB}$, Pols $\mathrm{DH}$, et al. Expression of somatostatin, cortistatin, and somatostatin receptors in human monocytes, macrophages, and dendritic cells. Am J Physiol Endocrinol Metab. 2003; 285: E344-53. doi:10.1152/ajpendo.00048.200300048.2003 [pii].

64. Rominger A, Saam T, Vogl E, Ubleis C, la Fougere C, Forster S, et al. In vivo imaging of macrophage activity in the coronary arteries using ${ }^{68}$ Ga-DOTATATE PET/CT: correlation with coronary calcium burden and risk factors. J Nucl Med. 2010; 51: 193-7. doi:10.2967/jnumed.109.070672.

65. Ambrosini V, Zompatori M, De Luca F, Antonia D, Allegri V, Nanni C, et al. ${ }^{68} \mathrm{Ga}-\mathrm{DOT} A N O C$ PET/CT allows somatostatin receptor imaging in idiopathic pulmonary fibrosis: preliminary results. J Nucl Med. 2010; 51: 1950-5. doi:jnumed.110.079962 [pii]10.2967/jnumed.110.079962.

66. Jindal T, Kumar A, Dutta R, Kumar R. Combination of ${ }^{18} \mathrm{~F}-\mathrm{FDG}$ and ${ }^{68} \mathrm{Ga}$-DOTATOC PET-CT to differentiate endobronchial carcinoids and inflammatory myofibroblastic tumors. J Postgrad Med. 2009; 55: 272-4. doi:jpgm_2009_55_4_272_58932 [pii]10.4103/0022-3859.58932.

67. Oberg K. Molecular Imaging Radiotherapy: Theranostics for Personalized Patient Management of Neuroendocrine Tumors (NETs). Theranostics. 2012; 2: 448-58. doi:10.7150/thno.3931.

68. Garske U, Sandstrom M, Johansson S, Granberg D, Lundqvist H, Lubberink $\mathrm{M}$, et al. Lessons on tumour response: Imaging during therapy with ${ }^{177} \mathrm{Lu}$-DOTA-octreotate. A case report on a patient with a large volume of poorly differentiated neuroendocrine carcinoma. Theranostics. 2012; 2: 459-71. doi:10.7150/thno.3594.

69. Delpassand ES, Samarghandi A, Mourtada JS, Zamanian S, Espenan GD, Sharif $\mathrm{R}$, et al. Long-term survival, toxicity profile, and role of F-18 FDG $\mathrm{PET} / \mathrm{CT}$ scan in patients with progressive neuroendocrine tumors following peptide receptor radionuclide therapy with high activity In-111 Pentetreotide. Theranostics. 2012; 2: 472-80. doi:10.7150/thno.3739.

70. Pettinato C, Sarnelli A, Di Donna M, Civollani S, Nanni C, Montini G, et al. ${ }^{6} \mathrm{Ga}$-DOTANOC: biodistribution and dosimetry in patients affected by neuroendocrine tumors. Eur J Nucl Med Mol Imaging. 2008; 35: 72-9. doi:10.1007/s00259-007-0587-y.

71. Hofmann M, Maecke H, Borner R, Weckesser E, Schoffski P, Oei L, et al. Biokinetics and imaging with the somatostatin receptor PET radioligand 
${ }^{68}$ Ga-DOTATOC: preliminary data. Eur J Nucl Med. 2001; 28: 1751-7. doi:10.1007/s002590100639.

72. Cabral GA, Raborn ES, Griffin L, Dennis J, Marciano-Cabral F. CB2 receptors in the brain: role in central immune function. Br J Pharmacol. 2008; 153: 240-51. doi:10.1038/sj.bjp.0707584.

73. Evens N, Bormans GM. Non-invasive imaging of the type 2 cannabinoid receptor, focus on positron emission tomography. Curr Top Med Chem. 2010; 10: 1527-43. doi:BSP/ CTMC /E-Pub/-0096-10-16 [pii].

74. Hostetler ED, Terry GE, Donald Burns H. An improved synthesis of substituted $\left[{ }^{11} \mathrm{C}\right]$ toluenes via Suzuki coupling with [11 C]methyl iodide. J Labelled Comp Radiopharm. 2005; 48: 629-34. doi:10.1002/jlcr.953.

75. Evens N, Vandeputte C, Muccioli GG, Lambert DM, Baekelandt V, Verbruggen AM, et al. Synthesis, in vitro and in vivo evaluation of fluorine-18 labelled FE-GW405833 as a PET tracer for type 2 cannabinoid receptor imaging. Bioorg Med Chem. 2011; 19: 4499-505. doi:S0968-0896(11)00461-5 [pii]10.1016/j.bmc.2011.06.033.

76. Horti AG, Gao Y, Ravert HT, Finley P, Valentine H, Wong DF, et al. Synthesis and biodistribution of $\left.{ }^{[11} \mathrm{C}\right] \mathrm{A}-836339$, a new potential radioligand for PET imaging of cannabinoid type 2 receptors (CB2). Bioorg Med Chem. 2010; 18: 5202-7. doi:S0968-0896(10)00489-X [pii]10.1016/j.bmc.2010.05.058

77. Evens N, Vandeputte C, Coolen C, Janssen P, Sciot R, Baekelandt V, et al. Preclinical evaluation of [11C]NE40, a type 2 cannabinoid receptor PET tracer. Nucl Med Biol. 2012; 39: 389-99. doi:S0969-8051(11)00218-6 [pii]10.1016/j.nucmedbio.2011.09.005.

78. Vandeputte C, Evens N, Toelen J, Deroose CM, Bosier B, Ibrahimi A, et al. A PET brain reporter gene system based on type 2 cannabinoid receptors. J Nucl Med. 2011; 52: 1102-9. doi:jnumed.110.084426 [pii]10.2967/jnumed.110.084426.

79. Stasiuk GJ, Smith H, Wylezinska-Arridge M, Tremoleda JL, Trigg W, Luthra SK, et al. $\mathrm{Gd}^{3+}$ cFLFLFK conjugate for MRI: a targeted contrast agent for FPR1 in inflammation. Chem Commun (Camb). 2013; 49: 564-6. doi:10.1039/c2cc37460a.

80. Xiao L, Zhang Y, Liu Z, Yang M, Pu L, Pan D. Synthesis of the Cyanine 7 labeled neutrophil-specific agents for noninvasive near infrared fluorescence imaging. Bioorg Med Chem Lett. 2010; 20: 3515-7. doi:10.1016/j.bmcl.2010.04.136.

81. Zhang Y, Xiao L, Chordia MD, Locke LW, Williams MB, Berr SS, et al. Neutrophil targeting heterobivalent SPECT imaging probe: cFLFLF-PEG-TKPPR-99mTc. Bioconjugate Chem. 2010; 21: 1788-93. doi:10.1021/bc100063a.

82. Locke LW, Chordia MD, Zhang Y, Kundu B, Kennedy D, Landseadel J, et al. A novel neutrophil-specific PET imaging agent: cFLFLFK-PEG-64 Cu. J Nucl Med. 2009; 50: 790-7. doi:10.2967/jnumed.108.056127.

83. Zhang Y, Kundu B, Fairchild KD, Locke L, Berr SS, Linden J, et al. Synthesis of novel neutrophil-specific imaging agents for positron emission tomography (PET) imaging. Bioorg Med Chem Lett. 2007; 17: 6876-8. doi:10.1016/j.bmcl.2007.10.013.

84. Tran L, Huitema AD, van Rijswijk MH, Dinant HJ, Baars JW, Beijnen JH, et al. CD20 antigen imaging with 124I-rituximab PET/CT in patients with rheumatoid arthritis. Hum Antibodies. 2011; 20; 29-35. doi:10.3233/HAB2011023910.3233/HAB-2011-0239.

85. Hawkey CJ. COX-2 inhibitors. Lancet. 1999; 353: 307-14. doi:S0140673698121542 [pii].

86. Katori M, Majima M. Cyclooxygenase-2: its rich diversity of roles and possible application of its selective inhibitors. Inflamm Res. 2000; 49: 367-92.

87. Minghetti L. Cyclooxygenase-2 (COX-2) in inflammatory and degenerative brain diseases. J Neuropathol Exp Neurol. 2004; 63: 901-10.

88. de Vries EF, van Waarde A, Buursma AR, Vaalburg W. Synthesis and in vivo evaluation of ${ }^{18} \mathrm{~F}$-desbromo-DuP-697 as a PET tracer for cyclooxygenase-2 expression. J Nucl Med. 2003; 44: 1700-6.

89. McCarthy TJ, Sheriff AU, Graneto MJ, Talley JJ, Welch MJ. Radiosynthesis, in vitro validation, and in vivo evaluation of $18 \mathrm{~F}-$-labeled COX-1 and COX-2 inhibitors. J Nucl Med. 2002; 43: 117-24.

90. Prabhakaran J, Majo VJ, Simpson NR, Van Heertum RL, Mann JJ, Kumar JSD. Synthesis of $\left.{ }^{[11} \mathrm{C}\right]$ celecoxib: a potential PET probe for imaging COX-2 expression. J Labelled Comp Radiopharm. 2005; 48: 887-95. doi:10.1002/jlcr.1002.

91. de Vries EFJ, Doorduin J, Dierckx RA, van Waarde A. Evaluation of $\left[{ }^{11} \mathrm{C}\right]$ rofecoxib as PET tracer for cyclooxygenase 2 overexpression in rat models of inflammation. Nucl Med Biol. 2008; 35: 35-42. doi:10.1016/j.nucmedbio.2007.07.015.

92. Shukuri M, Takashima-Hirano M, Tokuda K, Takashima T, Matsumura $\mathrm{K}$, Inoue $\mathrm{O}$, et al. In vivo expression of cyclooxygenase-1 in activated microglia and macrophages during neuroinflammation visualized by
PET with ${ }^{11}$ C-ketoprofen methyl ester. J Nucl Med. 2011; 52: 1094-101. doi:jnumed.110.084046 [pii]10.2967/jnumed.110.084046.

93. de Vries EFJ, Doorduin J, Vellinga NAR, van Waarde A, Dierckx RA, Klein HC. Can celecoxib affect P-glycoprotein-mediated drug efflux? A microPET study. Nucl Med Biol. 2008; 35: 459-66. doi:10.1016/j.nucmedbio.2008.01.005.

94. Gao M, Wang M, Miller KD, Zheng QH. Synthesis and preliminary in vitro biological evaluation of new carbon-11-labeled celecoxib derivatives as candidate PET tracers for imaging of COX-2 expression in cancer. Eur J Med Chem. 2011; 46: 4760-7. doi:S0223-5234(11)00402-8 [pii]10.1016/j.ejmech.2011.05.024.

95. Wuest F, Kniess T, Bergmann R, Pietzsch J. Synthesis and evaluation in vitro and in vivo of a ${ }^{11} \mathrm{C}$-labeled cyclooxygenase-2 (COX-2) inhibitor. Bioorg Med Chem. 2008; 16: 7662-70. doi:S0968-0896(08)00619-6 [pii]10.1016/j.bmc.2008.07.016.

96. Uddin MJ, Crews BC, Ghebreselasie K, Huda I, Kingsley PJ, Ansari MS, et al. Fluorinated COX-2 Inhibitors as Agents in PET Imaging of Inflammation and Cancer. Cancer Prev Res (Phila). 2011; 4: 1536-45. doi:10.1158/1940-6207.capr-11-0120.

97. Egeblad M, Werb Z. New functions for the matrix metalloproteinases in cancer progression. Nat Rev Cancer. 2002; 2: 161-74. doi:10.1038/nrc745.

98. Ryu JH, Lee A, Huh MS, Chu J, Kim K, Kim BS, et al. Measurement of MMP activity in synovial fluid in cases of osteoarthritis and acute inflammatory conditions of the knee joints using a fluorogenic peptide probe-immobilized diagnostic kit. Theranostics. 2012; 2: 198-206. doi: $10.7150 /$ thno. 3477 .

99. Yhee JY, Kim SA, Koo H, Son S, Ryu JH, Youn IC, et al. Optical imaging of cancer-related proteases using near-infrared fluorescence matrix metalloproteinase-sensitive and cathepsin B-sensitive probes. Theranostics. 2012; 2: 179-89. doi:10.7150/thno.3716.

100. Zhu L, Xie J, Swierczewska M, Zhang F, Quan Q, Ma Y, et al. Real-time video imaging of protease expression in vivo. Theranostics. 2011; 1 : 18-27.

101. Zhu L, Wang H, Wang L, Wang Y, Jiang K, Li C, et al. High-affinity peptide against MT1-MMP for in vivo tumor imaging. J Control Release. 2011; 150: 248-55. doi:10.1016/j.jconrel.2011.01.032.

102. Zhu L, Zhang F, Ma Y, Liu G, Kim K, Fang X, et al. In vivo optical imaging of membrane-type matrix metalloproteinase (MT-MMP) activity. Mol Pharm. 2011; 8: 2331-8. doi:10.1021/mp2002297.

103. Hermann S, Starsichova A, Waschkau B, Kuhlmann M, Wenning C, Schober O, et al. Non-FDG imaging of atherosclerosis: will imaging of MMPs assess plaque vulnerability? J Nucl Cardiol. 2012; 19: 609-17. doi:10.1007/s12350-012-9553-6.

104. Schafers M, Riemann B, Kopka K, Breyholz HJ, Wagner S, Schafers KP, et al. Scintigraphic imaging of matrix metalloproteinase activity in the arterial wall in vivo. Circulation. 2004; 109: 2554-9. doi:10.1161/01.CIR.0000129088.49276.8301.CIR.0000129088.49276.83 [pii].

105. Kuge $Y$, Takai N, Ogawa $Y$, Temma T, Zhao $Y$, Nishigori $K$, et al. Imaging with radiolabelled anti-membrane type 1 matrix metalloproteinase (MT1-MMP) antibody: potentials for characterizing atherosclerotic plaques. Eur J Nucl Med Mol Imaging. 2010; 37: 2093-104. doi:10.1007/s00259-010-1521-2.

106. Sprague JE, Li WP, Liang K, Achilefu S, Anderson CJ. In vitro and in vivo investigation of matrix metalloproteinase expression in metastatic tumor models. Nucl Med Biol. 2006; 33: 227-37. doi:S0969-8051(05)00271-4 [pii]10.1016/j.nucmedbio.2005.10.011.

107. Zheng QH, Fei X, Liu X, Wang JQ, Bin Sun H, Mock BH, et al. Synthesis and preliminary biological evaluation of MMP inhibitor radiotracers [11 C]methyl-halo-CGS 27023A analogs, new potential PET breast cancer imaging agents. NuclMed Biol. 2002; 29: 761-70. doi:S0969805102003384 [pii].

108. Hartung D, Schafers M, Fujimoto S, Levkau B, Narula N, Kopka K, et al. Targeting of matrix metalloproteinase activation for noninvasive detection of vulnerable atherosclerotic lesions. European journal of nuclear medicine and molecular imaging. 2007; 34 Suppl 1: S1-8. doi:10.1007/s00259-007-0435-0.

109. Kintscher U, Hartge M, Hess K, Foryst-Ludwig A, Clemenz M, Wabitsch $\mathrm{M}$, et al. T-lymphocyte infiltration in visceral adipose tissue: a primary event in adipose tissue inflammation and the development of obesity-mediated insulin resistance. Arterioscler Thromb Vasc Biol. 2008; 28: 1304-10. doi:ATVBAHA.108.165100 [pii]10.1161/ATVBAHA. 108.165100

110. Signore A, Picarelli A, Annovazzi A, Britton KE, Grossman AB, Bonanno $\mathrm{E}$, et al. 123I-Interleukin-2: biochemical characterization and in vivo use for imaging autoimmune diseases. Nucl Med Comm. 2003; 24: 305-16. doi:10.1097/01.mnm.0000061052.02423.2c. 
111. Signore A, Chianelli M, Annovazzi A, Rossi M, Maiuri L, Greco M, et al. Imaging active lymphocytic infiltration in coeliac disease with iodine-123-interleukin-2 and the response to diet. Eur J Nucl Med. 2000; 27: $18-24$

112. Annovazzi A, Bonanno E, Arca M, D'Alessandria C, Marcoccia A, Spagnoli LG, et al. 99mTc-interleukin-2 scintigraphy for the in vivo imaging of vulnerable atherosclerotic plaques. Eur J Nucl Med Mol Imaging. 2006; 33: 117-26. doi:10.1007/s00259-005-1899-4.

113. Di Gialleonardo V, Signore A, Glaudemans AW, Dierckx RA, De Vries EF. N-(4-18F-fluorobenzoyl)interleukin-2 for PET of human-activated T lymphocytes. J Nucl Med. 2012; 53: 679-86. doi:10.2967/jnumed. 111.091306.

114. Di Gialleonardo V, Signore A, Willemsen AT, Sijbesma JW, Dierckx RA, de Vries EF. Pharmacokinetic modelling of $\mathrm{N}-\left(4-\left[{ }^{18} \mathrm{~F}\right]\right.$ fluorobenzoyl)interleukin-2 binding to activated lymphocytes in an xenograft model of inflammation. Eur J Nucl Med Mol Imaging. 2012; 39: 1551-60. doi:10.1007/s00259-012-2176-y.

115. Cairns CB, Panacek EA, Harken AH, Banerjee A. Bench to bedside: tumor necrosis factor-alpha: from inflammation to resuscitation. Acad Emerg Med. 2000; 7: 930-41.

116. Cao Q, Cai W, Li ZB, Chen K, He L, Li HC, et al. PET imaging of acute and chronic inflammation in living mice. Eur J Nucl Med Mol Imaging. 2007; 34: 1832-42. doi:10.1007/s00259-007-0451-0.

117. Gao M, Lola CM, Wang M, Miller KD, Sledge GW, Hutchins GD, et al. Synthesis of carbon-11-labeled tricyclic necroptosis inhibitors as new potential PET agents for imaging of tumor necrosis factor alpha (TNF-alpha). Appl Radiat Isot. 2010; 68: 1950-8. doi:10.1016/j.apradiso.2010.04.030.

118. Desgrosellier JS, Cheresh DA. Integrins in cancer: biological implications and therapeutic opportunities. Nat Rev Cancer. 2010; 10: 9-22. doi:nrc2748 [pii]10.1038/nrc2748.

119. Hodivala-Dilke K. alphavbeta3 integrin and angiogenesis: a moody integrin in a changing environment. Curr Opin Cell Biol. 2008; 20: 514-9. doi:S0955-0674(08)00117-8 [pii]10.1016/j.ceb.2008.06.007.

120. Antonov AS, Kolodgie FD, Munn DH, Gerrity RG. Regulation of macrophage foam cell formation by alphaVbeta3 integrin: potential role in human atherosclerosis. Am J Pathol. 2004; 165: 247-58.

121. Antonov AS, Antonova GN, Munn DH, Mivechi N, Lucas R, Catravas $\mathrm{JD}$, et al. alphaVbeta3 integrin regulates macrophage inflammatory responses via PI3 kinase/Akt-dependent NF-kappaB activation. J Cell Physiol. 2011; 226: 469-76. doi:10.1002/jcp.22356.

122. Niu G, Chen $X$. Why integrin as a primary target for imaging and therapy. Theranostics. 2011; 1: 30-47.

123. Zhu L, Guo N, Li Q, Ma Y, Jacboson O, Lee S, et al. Dynamic PET and Optical Imaging and Compartment Modeling using a Dual-labeled Cyclic RGD Peptide Probe. Theranostics. 2012; 2: 746-56. doi: $10.7150 /$ thno.4762.

124. Beer AJ, Kessler H, Wester HJ, Schwaiger M. PET Imaging of Integrin alphaVbeta3 Expression. Theranostics. 2011; 1: 48-57.

125. Gaertner FC, Kessler H, Wester HJ, Schwaiger M, Beer AJ. Radiolabelled RGD peptides for imaging and therapy. Eur J Nucl Med Mol Imaging. 2012; 39 Suppl 1: S126-38. doi:10.1007/s00259-011-2028-1.

126. Danese S, Sans M, de la Motte C, Graziani C, West G, Phillips MH, et al. Angiogenesis as a novel component of inflammatory bowel disease pathogenesis. Gastroenterology. 2006; 130: 2060-73. doi:S0016-5085(06)00739-6 [pii]10.1053/j.gastro.2006.03.054.

127. Wilder RL. Integrin alpha $\mathrm{V}$ beta 3 as a target for treatment of rheumatoid arthritis and related rheumatic diseases. Ann Rheum Dis. 2002; 61 Suppl 2: ii96-9.

128. Aziz MM, Ishihara S, Mishima Y, Oshima N, Moriyama I, Yuki T, et al. MFG-E8 attenuates intestinal inflammation in murine experimental colitis by modulating osteopontin-dependent alphavbeta3 integrin signaling. J Immunol. 2009; 182: 7222-32. doi:182/11/7222 [pii]10.4049/jimmunol.0803711.

129. Pichler BJ, Kneilling M, Haubner R, Braumuller H, Schwaiger M, Rocken $\mathrm{M}$, et al. Imaging of delayed-type hypersensitivity reaction by PET and 18F-galacto-RGD. J Nucl Med. 2005; 46: 184-9. doi:46/1/184 [pii].

130. Laitinen I, Saraste A, Weidl E, Poethko T, Weber AW, Nekolla SG, et al. Evaluation of alphavbeta3 integrin-targeted positron emission tomography tracer ${ }^{18} \mathrm{~F}$-galacto-RGD for imaging of vascular inflammation in atherosclerotic mice. Circ Cardiovas Imaging. 2009; 2: 331-8. doi:CIRCIMAGING.108.846865 [pii]10.1161/CIRCIMAGING. 108.846865

131. Saraste A, Laitinen I, Weidl E, Wildgruber M, Weber AW, Nekolla SG, et al. Diet intervention reduces uptake of alphavbeta3 integrin-targeted PET tracer $18 \mathrm{~F}$-galacto-RGD in mouse atherosclerotic plaques. J Nucl Cardiol. 2012; 19: 775-84. doi:10.1007/s12350-012-9554-5.
132. Johanna H, Iina L, Pauliina L, Peter I, Ian W, Hege K, et al. ${ }^{68} \mathrm{Ga}$-DOTA-RGD peptide: biodistribution and binding into atherosclerotic plaques in mice. Eur J Nucl Med Mol Imaging. 2009; 36: 2058-67. doi:10.1007/s00259-009-1220-z.

133. Salmi M, Jalkanen S. VAP-1: an adhesin and an enzyme. Trends Immunol. 2001; 22: 211-6. doi:S1471-4906(01)01870-1 [pii].

134. Autio A, Henttinen T, Sipila HJ, Jalkanen S, Roivainen A. Mini-PEG spacering of VAP-1-targeting ${ }^{68} \mathrm{Ga}$-DOTAVAP-P1 peptide improves PET imaging of inflammation. EJNMMI Res. 2011; 1: 10. doi:10.1186/2191-219X-1-10.

135. Silvola J, Autio A, Luoto P, Jalkanen S, Roivainen A. Preliminary evaluation of novel ${ }^{68} \mathrm{Ga}$-DOTAVAP-PEG-P2 peptide targeting vascular adhesion protein-1. Clin Physiol Funct Imaging. 2010; 30: 75-8. doi:10.1111/j.1475-097X.2009.00907.x.

136. Aalto K, Autio A, Kiss EA, Elima K, Nymalm Y, Veres TZ, et al. Siglec-9 is a novel leukocyte ligand for vascular adhesion protein-1 and can be used in PET imaging of inflammation and cancer. Blood. 2011; 118: 3725-33. doi:10.1182/blood-2010-09-311076.

137. Lankinen P, Makinen TJ, Poyhonen TA, Virsu P, Salomaki S, Hakanen AJ, et al. ${ }^{68} \mathrm{Ga}$-DOTAVAP-P1 PET imaging capable of demonstrating the phase of inflammation in healing bones and the progress of infection in osteomyelitic bones. Eur J Nucl Med Mol Imaging. 2008; 35: 352-64. doi:10.1007/s00259-007-0637-5.

138. Ujula T, Salomaki S, Virsu P, Lankinen P, Makinen TJ, Autio A, et al. Synthesis, ${ }^{68} \mathrm{Ga}$ labeling and preliminary evaluation of DOTA peptide binding vascular adhesion protein-1: a potential PET imaging agent for diagnosing osteomyelitis. Nucl Med Biol. 2009; 36: 631-41. doi:S0969-8051(09)00114-0 [pii]10.1016/j.nucmedbio.2009.04.008.

139. Fotis L, Agrogiannis G, Vlachos IS, Pantopoulou A, Margoni A, Kostaki $\mathrm{M}$, et al. Intercellular adhesion molecule (ICAM)- 1 and vascular cell adhesion molecule (VCAM)-1 at the early stages of atherosclerosis in a rat model. In Vivo. 2012; 26: 243-50. doi:26/2/243 [pii].

140. Ley K, Huo Y. VCAM-1 is critical in atherosclerosis. J Clin Invest. 2001; 107: 1209-10. doi:10.1172/JCI13005.

141. Nahrendorf M, Keliher E, Panizzi P, Zhang H, Hembrador S, Figueiredo $\mathrm{JL}$, et al. ${ }^{18} \mathrm{~F}-4 \mathrm{~V}$ for PET-CT imaging of VCAM-1 expression in atherosclerosis. JACC Cardiovas Imaging. 2009; 2: 1213-22. doi:S1936-878X(09)00529-4 [pii]10.1016/j.jcmg.2009.04.016.

142. Tsan MF. Mechanism of gallium-67 accumulation in inflammatory lesions. J Nucl Med. 1985; 26: 88-92.

143. Nanni C, Errani C, Boriani L, Fantini L, Ambrosini V, Boschi S, et al. ${ }^{68} \mathrm{Ga}$-citrate PET/CT for evaluating patients with infections of the bone: preliminary results. J Nucl Med. 2010; 51: 1932-6. doi:10.2967/jnumed.110.080184.

144. Makinen TJ, Lankinen P, Poyhonen T, Jalava J, Aro HT, Roivainen A. Comparison of ${ }^{18} \mathrm{~F}-\mathrm{FDG}$ and ${ }^{68} \mathrm{Ga}$ PET imaging in the assessment of experimental osteomyelitis due to Staphylococcus aureus. Eur J Nucl Med Mol Imaging. 2005; 32: 1259-68. doi:10.1007/s00259-005-1841-9.

145. Ross R. Atherosclerosis--an inflammatory disease. N Engl J Med. 1999; 340: 115-26. doi:10.1056/NEJM199901143400207.

146. McGeer PL, McGeer EG. The inflammatory response system of brain: implications for therapy of Alzheimer and other neurodegenerative diseases. Brain Res Brain Res Rev. 1995; 21: 195-218.

147. Philip M, Rowley DA, Schreiber H. Inflammation as a tumor promoter in cancer induction. Semin Cancer Biol. 2004; 14: 433-9. doi:10.1016/j.semcancer.2004.06.006.

148. Hiari N, Rudd JH. FDG PET imaging and cardiovascular inflammation. Curr Cardiol Rep. 2011; 13: 43-8. doi:10.1007/s11886-010-0150-5.

149. Sheikine Y, Akram K. FDG-PET imaging of atherosclerosis: Do we know what we see? Atherosclerosis. 2010; 211: 371-80. doi:10.1016/j.atherosclerosis.2010.01.002.

150. Streit WJ, Mrak RE, Griffin WS. Microglia and neuroinflammation: a pathological perspective. J Neuroinflammation. 2004; 1: 14 . doi:10.1186/1742-2094-1-14.

151. Jacobs AH, Tavitian B. Noninvasive molecular imaging of neuroinflammation. J Cereb Blood Flow Metab. 2012; 32: 1393-415. doi:10.1038/jcbfm.2012.53.

152. Yokokura M, Mori N, Yagi S, Yoshikawa E, Kikuchi M, Yoshihara Y, et al. In vivo changes in microglial activation and amyloid deposits in brain regions with hypometabolism in Alzheimer's disease. Eur J Nucl Med Mol Imaging. 2011; 38: 343-51. doi:10.1007/s00259-010-1612-0.

153. Gulyas B, Vas A, Toth M, Takano A, Varrone A, Cselenyi Z, et al. Age and disease related changes in the translocator protein (TSPO) system in the human brain: positron emission tomography measurements with $\left[{ }^{11} \mathrm{C}\right]$ vinpocetine. Neuroimage. 2011; 56: 1111-21. doi:10.1016/j. neuroimage.2011.02.020. 
154. Okello A, Edison P, Archer HA, Turkheimer FE, Kennedy J, Bullock R, et al. Microglial activation and amyloid deposition in mild cognitive impairment: a PET study. Neurology. 2009; 72: 56-62. doi:10.1212/01.wnl.0000338622.27876.0d.

155. Edison P, Archer HA, Gerhard A, Hinz R, Pavese N, Turkheimer FE, et al. Microglia, amyloid, and cognition in Alzheimer's disease: An $\left[{ }^{11} \mathrm{C}\right](\mathrm{R}) \mathrm{PK} 11195-\mathrm{PET}$ and $\left[{ }^{11} \mathrm{C}\right] \mathrm{PIB}-\mathrm{PET}$ study. Neurobiol Dis. 2008; 32: 412-9. doi:10.1016/j.nbd.2008.08.001S0969-9961(08)00188-5 [pii].

156. Edison P, Ahmed I, Fan Z, Hinz R, Gelosa G, Ray Chaudhuri K, et al. Microglia, amyloid, and glucose metabolism in Parkinson's disease with and without dementia. Neuropsychopharmacology. 2013; 38: 938-49. doi:10.1038/npp.2012.255.

157. Thiel A, Radlinska BA, Paquette C, Sidel M, Soucy JP, Schirrmacher R, et al. The temporal dynamics of poststroke neuroinflammation: a longitudinal diffusion tensor imaging-guided PET study with ${ }^{11 C-P K 11195 ~ i n ~ a c u t e ~ s u b c o r t i c a l ~ s t r o k e . ~ J ~ N u c l ~ M e d . ~ 2010 ; ~ 51: ~ 1404-12 . ~}$ doi:10.2967/jnumed.110.076612.

158. Ramlackhansingh AF, Brooks DJ, Greenwood RJ, Bose SK, Turkheimer FE, Kinnunen KM, et al. Inflammation after trauma: microglial activation and traumatic brain injury. Ann Neurol. 2011; 70: 374-83. doi:10.1002/ana.22455.

159. Schweitzer PJ, Fallon BA, Mann JJ, Kumar JS. PET tracers for the peripheral benzodiazepine receptor and uses thereof. Drug Discov Today. 2010; 15: 933-42. doi:S1359-6446(10)00288-6 [pii]10.1016/j.drudis.2010.08.012.

160. Yu I, Inaji $M$, Maeda J, Okauchi $T$, Nariai $T$, Ohno $K$, et al. Glial cell-mediated deterioration and repair of the nervous system after traumatic brain injury in a rat model as assessed by positron emission tomography. J Neurotrauma. 2010; 27: 1463-75. doi:10.1089/neu.2009.1196.

161. Folkersma H, Foster Dingley JC, van Berckel BN, Rozemuller A, Boellaard R, Huisman MC, et al. Increased cerebral (R)-[11C]PK11195 uptake and glutamate release in a rat model of traumatic brain injury: a longitudinal pilot study. J Neuroinflammation. 2011; 8: 67. doi:10.1186/1742-2094-8-67.

162. Martin A, Boisgard R, Theze B, Van Camp N, Kuhnast B, Damont A, et al. Evaluation of the PBR/TSPO radioligand [ $\left.{ }^{18} \mathrm{~F}\right] \mathrm{DPA}-714$ in a rat model of focal cerebral ischemia. J Cereb Blood Flow Metab. 2010; 30: 230-41. doi:10.1038/jcbfm.2009.205.

163. Xie L, Yamasaki T, Ichimaru N, Yui J, Kawamura K, Kumata K, et al. [11C]DAC-PET for noninvasively monitoring neuroinflammation and immunosuppressive therapy efficacy in rat experimental autoimmune encephalomyelitis model. J Neuroimmune Pharmacol. 2012; 7: 231-42. doi:10.1007/s11481-011-9322-3.

164. Gerhard A, Pavese N, Hotton G, Turkheimer F, Es M, Hammers A, et al. In vivo imaging of microglial activation with $\left.{ }^{11} \mathrm{C}\right](\mathrm{R})-\mathrm{PK} 11195$ PET in idiopathic Parkinson's disease. Neurobiol Dis. 2006; 21: 404-12. doi:10.1016/j.nbd.2005.08.002.

165. Politis M, Pavese N, Tai YF, Kiferle L, Mason SL, Brooks DJ, et al. Microglial activation in regions related to cognitive function predicts disease onset in Huntington's disease: a multimodal imaging study. Hum Brain Mapp. 2011; 32: 258-70. doi:10.1002/hbm.21008.

166. Mantovani A, Allavena P, Sica A, Balkwill F. Cancer-related inflammation. Nature. 2008; 454: 436-44. doi:10.1038/nature07205.

167. Cottone L, Valtorta S, Capobianco A, Belloli S, Rovere-Querini P, Fazio F, et al. Evaluation of the role of tumor-associated macrophages in an experimental model of peritoneal carcinomatosis using 18F-FDG PET. J Nucl Med. 2011; 52: 1770-7. doi:10.2967/jnumed.111.089177.

168. Solinas G, Germano G, Mantovani A, Allavena P. Tumor-associated macrophages (TAM) as major players of the cancer-related inflammation. J Leukoc Biol. 2009; 86: 1065-73. doi:10.1189/jlb.0609385.

169. Zhang W, Zhu X-D, Sun H-C, Xiong Y-Q, Zhuang P-Y, Xu H-X, et al. Depletion of tumor-associated macrophages enhances the effect of Sorafenib in metastatic liver cancer models by antimetastatic and antiangiogenic effects. Clin Cancer Res. 2010; 16: 3420-30. doi:10.1158/1078-0432.ccr-09-2904.

170. Daldrup-Link H, Coussens LM. MR imaging of tumor-associated macrophages. Oncoimmunology. 2012; 1: 507-9.

171. Verdoes M, Edgington Laura E, Scheeren FA, Leyva M, Blum G, Weiskopf K, et al. A nonpeptidic cathepsin S activity-based probe for noninvasive optical imaging of tumor-associated macrophages. Chem Biol. 2012; 19: 619-28. doi: 10.1016/j.chembiol.2012.03.012.

172. Locke LW, Mayo MW, Yoo AD, Williams MB, Berr SS. PET imaging of tumor associated macrophages using mannose coated ${ }^{64} \mathrm{Cu}$ liposomes. Biomaterials. 2012; 33: 7785-93. doi: 10.1016/j. biomaterials.2012.07.022
173. Movahedi K, Schoonooghe S, Laoui D, Houbracken I, Waelput W, Breckpot $\mathrm{K}$, et al. Nanobody-based targeting of the macrophage mannose receptor for effective in vivo imaging of tumor-associated macrophages. Cancer Res. 2012; 72: 4165-77. doi:10.1158/0008-5472.CAN-11-2994

174. Nahrendorf M, Keliher E, Marinelli B, Waterman P, Feruglio PF, Fexon L, et al. Hybrid PET-optical imaging using targeted probes. Proc Natl Acad Sci U S A. 2010; 107: 7910-5. doi:10.1073/pnas.0915163107.

175. Melancon MP, Lu W, Huang Q, Thapa P, Zhou D, Ng C, et al. Targeted imaging of tumor-associated M2 macrophages using a macromolecular contrast agent PG-Gd-NIR813. Biomaterials. 2010; 31: 6567-73. doi:10.1016/j.biomaterials.2010.05.001.

176. Zheng J, Boisgard R, Siquier-Pernet K, Decaudin D, Dolle F, Tavitian B. Differential expression of the $18 \mathrm{kDa}$ translocator protein (TSPO) by neoplastic and inflammatory cells in mouse tumors of breast cancer. Mol Pharm. 2011; 8: 823-32. doi:10.1021/mp100433c.

177. van Waarde A, Elsinga PH. Proliferation markers for the differential diagnosis of tumor and inflammation. Curr Pharm Des. 2008; 14: 3326-339.

178. Lee TS, Ahn SH, Moon BS, Chun KS, Kang JH, Cheon GJ, et al. Comparison of ${ }^{18} \mathrm{~F}-\mathrm{FDG},{ }^{18} \mathrm{~F}-\mathrm{FET}$ and ${ }^{18} \mathrm{~F}-\mathrm{FLT}$ for differentiation between tumor and inflammation in rats. Nucl Med Biol. 2009; 36: 681-6. doi:10.1016/j.nucmedbio.2009.03.009.

179. Tsuji AB, Kato K, Sugyo A, Okada M, Sudo H, Yoshida C, et al. Comparison of 2-amino-[3-11C]isobutyric acid and 2-deoxy-2-[18F]fluoro-D-glucose in nude mice with xenografted tumors and acute inflammation. Nucl Med Comm. 2012; 33: 1058-64. doi:10.1097/MNM.0b013e328356efb0.

180. Koglin N, Mueller A, Berndt M, Schmitt-Willich H, Toschi L, Stephens $\mathrm{AW}$, et al. Specific PET imaging of $\mathrm{xC}$ - transporter activity using a ${ }^{18} \mathrm{~F}$-labeled glutamate derivative reveals a dominant pathway in tumor metabolism. Clin Cancer Res. 2011; 17: 6000-11. doi:10.1158/1078-0432.CCR-11-0687.

181. Weber WA. Monitoring tumor response to therapy with 18 F-FLT PET. J Nucl Med. 2010; 51: 841-4. doi:10.2967/jnumed.109.071217.

182. Sun X, Yan Y, Liu S, Cao Q, Yang M, Neamati N, et al. ${ }^{18} \mathrm{~F}-\mathrm{FPPRGD} 2$ and 18F-FDG PET of response to Abraxane therapy. J Nucl Med. 2011; 52: 140-6. doi:10.2967/jnumed.110.080606. 